\title{
Pater Optime: Vergilian Allusion in Obrecht's Mille Quingentis
}

\section{Citation}

Gallagher, Sean. 2001. Pater optime: Vergilian allusion in Obrecht's Mille quingentis. Journal of Musicology 18(3): 406-457.

\section{Published Version}

doi:10.1525/jm.2001.18.3.406

\section{Permanent link}

http://nrs.harvard.edu/urn-3:HUL.InstRepos:3776966

\section{Terms of Use}

This article was downloaded from Harvard University's DASH repository, and is made available under the terms and conditions applicable to Other Posted Material, as set forth at http:// nrs.harvard.edu/urn-3:HUL.InstRepos:dash.current.terms-of-use\#LAA

\section{Share Your Story}

The Harvard community has made this article openly available.

Please share how this access benefits you. Submit a story.

\section{Accessibility}




\section{Pater optime: Vergilian Allusion in Obrecht's Mille quingentis}

SEAN GALLAGHER

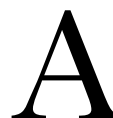

mong the various themes that animate Vergil's Aeneid, perhaps the most affecting in its persistence is that of a son's duty to his father. Father-son pairs appear throughout the epic, though not surprisingly it is in the depictions of Aeneas's behavior towards his father, Anchises, that the theme of filial devotion, with all its emotional and ethical associations, emerges most forcefully. Medieval and renaissance commentators interested in explicating the poem as a Christianized moral or spiritual allegory at times measure Aeneas's progress against the backdrop of his relationship with his father, a relationship that outlasts even Anchises's death. Indeed, for many readers, ancient and modern alike, Aeneas's actions following his father's death constitute the most significant demonstrations of his filial pietas.

Pius Aeneas, as he is so often described in the poem, is duty-bound in more ways than one-to his family, to the gods, to the memory of Troy, to his mission to conquer Italy-but as much as anything it is his devotion to Anchises that Vergil emphasizes in the first six books of the

Volume XVIII • Number 3 - Summer 2001

The Journal of Musicology (c) 2001 by the Regents of the University of California

A shorter version of this study was presented in 1997 at the 16 th Congress of the International Musicological Society. An abstract of that version has been published in Musicology and sister disciplines: past, present, future. Proceedings of the I 6th International Congress of the International Musicological Society, London, I997, ed. David Greer with Ian Rumbold and Jonathan King (New York: Oxford Univ. Press, 2000), 6o3. I wish to thank Charles Segal and Lino Pertile for much sound advice during the initial stages of my research on this topic. For their careful reading of the text and many helpful suggestions I am indebted to Bonnie J. Blackburn, James Haar, Leofranc Holford-Strevens, and Lewis Lockwood. 
Aeneid. Four events described in these books articulate the nature and extent of this sense of duty toward his father. First, there is their flight from Troy as the city is being sacked, a scene depicted in so many paintings and illuminations. Aeneas, having convinced the initially reluctant Anchises to escape with him, lifts the older man onto his back and takes the hand of his own son Ascanius, thereby forming "the group of figures which will symbolize pietas for the whole tradition of the West": ${ }^{1}$

ergo age, care pater, cervici imponere nostrae;

ipse subibo umeris nec me labor iste gravabit;

quo res cumque cadent, unum et commune periclum, una salus ambobus erit ... (Aen. 2.707-710)

Come then, dear father, place yourself on my neck. On my shoulders I shall bear you, and you shall be no burden for me. Whatever may happen, we shall face one common danger and find one salvation, together.

Second, after difficult years of sea travel and failed settlements, and following an aborted attempt to reach Italy, the Trojans make landfall in Sicily, where Anchises unexpectedly dies. Book 3 of the poem, in which Aeneas recounts all this to Dido and her court in Carthage, ends with his brief and moving lament for Anchises, whom he apostrophizes as "pater optime" ("O best of fathers"). ${ }^{2}$ Returning the following year to Sicily, Aeneas makes offerings at the site of his father's funeral mound on the anniversary of his death. Afterwards, the Trojans further honor his memory through ritualistic funeral games (ship races, running, boxing, archery), with the participants competing for the palm of victory. 3 And finally, in Book 6, a section of the epic that has always generated extensive commentary, Aeneas requests of the Cumaean Sibyl that he be allowed to descend to the underworld in order to see his father again, Anchises's spirit having visited him in the night commanding him to do so. 4 The detailed description of Aeneas's descent and his

1 M. Owen Lee, Fathers and Sons in Virgil's Aeneid: Tum Genitor Natum (Albany: State Univ. of New York Press, 1979), 42-44.

${ }^{2}$ Aen. 3.710; The Aeneid, ed. John William Mackail (Oxford: Clarendon Press, 1930) [except where noted, quotations from the Latin follow this edition].

3 Aen. 5.70 cuncti adsint meritaeque exspectent praemia palmae.

4 Aen. 5.721-740; 6 passim. Throughout the medieval period and later, Book 6 of the poem prompted the most commentary and speculation in terms of its moral, philosophical, and eschatological ramifications. It is indicative of the fascination this part of the work held for medieval writers that in the commentary attributed to Bernardus Silvestris his remarks on Book 6 are more than four times longer than those on the previous five books of the poem combined; The Commentary on the First Six Books of the Aeneid of 
joyful meeting with Anchises in Elysium, with father explaining to son the secrets of the anima mundi and showing him the future of his line, marks the climax of the first half of the epic. Book 6 marks Anchises's last appearance in the poem as well, bringing to a close the journey begun at the fall of Troy. Vergil, ever aware of such parallels, has Anchises greet his son in the underworld with an explicit reference to the filial pietas that had moved Aeneas to bear his father on his shoulders:

Tears were streaming down his cheeks, and a cry of joy fell from his lips: 'Have you come at last? Has the pietas in which your father hoped brought your bitter journey to its end?'5

The present study explores how certain fifteenth-century readers, in particular the composer Jacob Obrecht (ca. 1457/58-1505) and some of his contemporaries, might have known and understood the journey of Anchises and Aeneas. The focus here will be on the motet Mille quingentis-Requiem, Obrecht's remarkable musical epitaph for his father, Willem. The motet's text contains two brief quotations from Vergil's Eclogues, a fact noted 6o years ago in the first published assessment of the piece. ${ }^{6}$ In the extensive literature on Mille quingentis that has since appeared, scholars have mostly ignored these Vergilian tags or else passed over them as an incidental feature of the poem. With the goal of uncovering in it biographical details of various sorts, they have approached the text more or less literally and sought to identify historical scenarios that could plausibly support such readings. This way of interpreting the motet has resulted in biographical red herrings concerning both Jacob and his father, some of which are still with us. More seriously, previous readings, in minimizing the significance of figurative language, have proceeded from the premise that the main purpose of this short poem was to provide biographical data on the two men. In so doing they have tended also to close off from consideration a nexus of literary practices and religious themes that the writing of such a text presupposes.

Vergil Commonly Attributed to Bernardus Silvestris, ed. Julian Ward Jones and Elizabeth Frances Jones (Lincoln: Univ. of Nebraska Press, 1977). For an English translation (though one to be used with caution), see Commentary on the First Six Books of Virgil's Aeneid by Bernardus Silvestris, trans. Earl G. Schreiber and Thomas E. Maresca (Lincoln: Univ. of Nebraska Press, 1979).

5 Aen. 6.686-688 effusaeque genis lacrimae et vox excidit ore: Venisti tandem, tuaque exspectata parenti. vicit iter durum pietas?; trans. Lee, Fathers and Sons, 64. Anchises's reference here to the iter durum also provides an echo of Aeneas's lament for him: Hic labor extremus, longarum haec meta viarum (3.714) ("This was my last trial, this the goal of my long voyaging").

6 Albert Smijers, "Twee onbekende motetteksten van Jacob Obrecht," Tijdschrift van de vereniging voor nederlandse muziekgeschiedenis 16 (1941): 129-34. 
In place of this literalist approach, I propose that the motet's quotations from and allusions to works by Vergil are essential to understanding several parts of the poem and how these contribute to its significance as a commemorative work. In particular, an allusion to events described in Book 3 of the Aeneid, to be discussed below, suggests that the author (almost certainly Obrecht himself) wished to create associative links between the two father-son pairs, Willem/Jacob and Anchises/ Aeneas. In so doing he was participating in a tradition of commemorative poetry in which the assimilation of well-known classical texts into one's own writing served in part as a way to express personal sentiments using a "public" language newly charged with meaning.7 The poem draws on other textual sources besides Vergil, some of which might have mediated the author's understanding of Vergilian texts or even prompted him to turn to Vergil in the first place. Beyond the knowledge that by 1480 Obrecht had apparently obtained the degree of master of arts, what might broadly be called his intellectual biography-in particular where this extends beyond issues of musical composition-remains still in many ways uncharted territory. ${ }^{8}$ At issue here is not only Obrecht as a reader of texts (classical and otherwise), but also the modes of access to texts that would have shaped that reading and the larger web of readers and writers with whom he may have come into contact. A consideration of potential mediating texts of Mille quingentis, which include one of the treatises of the theorist Johannes Tinctoris, enables us to make some headway in this area and to indicate paths for future research.

Few texts live as deep in the bones of Western culture as the Aeneid. Any reading of the poem, even a brief and selective description of Aeneas's pietas such as the one provided above, is inevitably conditioned by a number of factors. Not least among these is the material factor of a reader's access to the text, or more precisely, to the forms in which the text most commonly circulates during a given period. True in principle for all texts, this material aspect impinges especially heavily where a work like the Aeneid is concerned. The availability today of numerous

7 Several examples, ranging from the first century to the sixteenth, are discussed further on in this study. Throughout the medieval period and later there appears to have been a close connection between the use of textual communes loci and the value placed on a well-stocked memory of such texts as "the essential foundation of prudence, sapientia, [and] ethical judgment"; see Mary Carruthers, The Book of Memory: A Study in Medieval Culture (Cambridge: Cambridge Univ. Press, 1990), esp. chap. 5, "Memory and the Ethics of Reading."

${ }^{8}$ Rob C. Wegman, Born for the Muses: The Life and Masses of Jacob Obrecht (Oxford: Clarendon Press, 1994) offers a rich account of Obrecht's career and development as a composer, highlighting his indebtedness to the music of Busnoys. Concerning Obrecht's university studies see chap. 3. Based on archival findings Wegman also provides much new information on the composer's parents and social background, including his father's contacts with the court of Charles the Bold (see also 177 below). 
editions, complete in many cases with critical commentary, encourages consideration of Vergil's epic in its entirety, as a whole made up of interrelated parts. That the notion of a highly integrated work shapes and informs most modern criticism on the Aeneid may seem self-evident, but it bears emphasizing here inasmuch as it reminds us of the impact the physical form of a text can have on its reception. Accordingly, in trying to understand how earlier periods might have read Vergil, a crucial first step is recognition of the types of material factors then operative. To be sure, the remarkable number of complete manuscript copies of the poem (and from the $147 \mathrm{os}$, printed editions) that survive from earlier centuries attests not only to Vergil's stature throughout the entire literary history of the West, but also to the likelihood that, in all periods, at least some readers possessed the means to study the epic as a whole. At the same time, one of the major achievements of recent Vergil scholarship has been an increased awareness of the extent to which readers in earlier centuries came to know his poetry through a variety of textual sources (florilegia, school texts, glosses, reworkings in the vernacular) .9 To speak of a medieval or renaissance reception of Vergil, then, is in part to recognize the effect these different modes of access would have 410 had on the ways readers attached meaning to his writings, on what and how much of his work they knew, and (where relevant) how they used his poetry in their own writings.

Mille quingentis likely dates from fairly soon after Willem Obrecht's death in 1488. It was thus written during an especially rich period in the long Nachleben of Vergil's poetry. It is in the second half of the $15^{\text {th }}$ century that we most clearly see medieval allegorical traditions, some with roots stretching back to antiquity, rubbing shoulders with newer humanistic approaches to the Aeneid, where the concerns are often as much literary as philosophical. The Christian assimilation of many classical Latin texts over the centuries provided a potential common ground for these different ways of reading Vergil and, as we shall see, made possible the use of his poetry in a devotional work such as Mille quingentis.

\section{Willem Obrecht's “Sicilian” Journey}

The text of Mille quingentis survives in only one of the motet's three sources, the Segovia Cathedral choirbook, a large collection of mostly

9 Two recent examples of this increasingly important area of Vergil scholarship are Christopher Baswell, Virgil in Medieval England: Figuring the Aeneid from the Twelfth Century to Chaucer (Cambridge: Cambridge Univ. Press, 1995) and Craig Kallendorf, Virgil and the Myth of Venice: Books and Readers in the Italian Renaissance (Oxford: Clarendon Press, 1999). 
Franco-Flemish polyphony, copied in Spain around $15^{\text {oo. }}{ }^{10}$ With 31 works attributed to him, Obrecht is the most heavily represented composer in the manuscript. Most of these pieces are motets and Middle Dutch songs, including 18 unica, making it a central source for his works in these genres. Moreover, beyond the sheer number of pieces by him, the unusual accuracy of its Middle Dutch texts lends the manuscript greater authority than its provenance (well outside the composer's known spheres of activity) might otherwise suggest. ${ }^{11}$ In 1936 Higinio Anglés published an inventory of the then unknown manuscript. ${ }^{12}$ Five years later the significance of the manuscript for Obrecht's biography became clear with the publication of Albert Smijers's article on the two autobiographical motets preserved in it, Mille

10 Segovia, Archivo Capitular de la Catedral, MS s. s., fols. $81 \mathrm{v}-8 \mathrm{~g}^{\mathrm{r}}$ (with the ascription "Jacobus Hobrecht"). This paper manuscript was copied possibly for the court of Isabella, Queen of Castile; Census-Catalogue of Manuscript Sources of Polyphonic Music I4ooI550, 5 vols., Renaissance Manuscript Studies 1 (Neuhausen-Stuttgart: American Institute of Musicology, 1979-88), 3: 137-38 and 4: 475; Reinhard Strohm, Music in Late Medieval Bruges, rev. ed. (Oxford: Clarendon Press, 1990), 142-44 (where the possibility is raised that Johannes Tinctoris might have had a hand in collecting the northern repertory found in the manuscript); Norma Klein Baker, "An Unnumbered Manuscript of Polyphony in the Archives of the Cathedral of Segovia: Its Provenance and History," 2 vols. (Ph.D. diss., Univ. of Maryland, 1978); facs. ed., Cancionero de la Catedral de Segovia, ed. Ramon Perales de la Cal (Segovia: Caja de Ahorros y Monte de Piedad, 1977). In Petrucci's Motetti $C$ (RISM ${ }_{1} 5^{\circ} 4^{1}$ ), where the work appears without attribution, all four voices carry the incipit of the cantus firmus text, "Requiem aeternam," with no further text provided. Similarly, in Florence, Biblioteca del Conservatorio, MS Basevi 2439, fols. $47 \mathrm{v}-48 \mathrm{r}$, which preserves only the motet's prima pars, there is only the incipit "Requiem" in one voice part; see facs. ed., Basevi Codex: Biblioteca del Conservatorio, MS 2439, introd. Honey Meconi (Peer: Alamire, 1990). Copied in the first decade of the 16 th century at the famous Brussels/Mechelen scriptorium, the manuscript is divided into two parts, with the first devoted primarily to four-voice works (including Obrecht's Fors seulement and three movements from his Missa Fortuna desperata, all ascribed to "Hobrecht"), the second to pieces in three-voices. Obrecht's "Requiem" was copied as an addition to the first part of the collection by a scribe other than the one responsible for most of the manuscript (here the ascription reads "Obreht"). Although the copying is competent, this scribe appears to have had difficulties accommodating the prima pars of the motet. The opening on which it was copied has seven staves (rather than the five or six found elsewhere in the manuscript), and is ruled for music in five parts. There are hand drawn extensions of staves, something the main scribe avoids almost entirely. A further indication of spacing problems is the Tenor part, which starts not at the indented beginning of the staff, but in the middle. The next opening in the manuscript (fols. $48 \mathrm{v}-49 \mathrm{r}$ ) is without music, but ruled for three voices. Possibly the scribe had available to him the long secunda pars of Mille quingentis but chose to omit it owing to the inappropriate ruling and fear of insufficient space. As it happens, Obrecht's motet (here without its text, of course) immediately follows a setting of an actual Vergilian text (fols. $46 \mathrm{v}-47 \mathrm{r}$ ): De Orto's four-voice Dulces exuviae (Aen. 4.65 1ff., Dido's last speech). 16th-century composers turned often to this passage in the Aeneid; more than a dozen settings are known.

11 Wegman, Born for the Muses, 22.

12 Higinio Anglés, "Un manuscrit inconnu avec polyphonie du XV siècle conservé à la cathedrale de Ségovie," Acta musicologica 8 (1936): 6-1 7. 
quingentis-Requiem aeternam and Inter praeclarissimas virtutes-Estote fortes in bello. ${ }^{13}$ Segovia is the unique source for the latter, a work that Rob Wegman has suggested Obrecht might have written in 1494-95 as a "musical letter of application" addressed to Pope Alexander VI. ${ }^{14}$ Only the text of Mille quingentis was new in Segovia, but this revealed that the motet, far from being the type of all-purpose Requiem its other two sources would suggest, had in fact been written to commemorate a specific event:

Mille quingentis verum bis sex minus annis

Virgine progeniti lapsis ab origine Christi,

Sicilides flerunt Muse, dum fata tulerunt

Hobrecht Guillermum, magna probitate decorum,

Cecilie ad festum, qui Ceciliam peragravit

Oram; idem Orpheicum Musis Jacobum generavit,

Ergo dulce melos succentorum chorus alme

Concine ut ad celos sit vecta anima et data palme.

After fifteen hundred less twice six years had lapsed since the birth of Christ, Son of the Virgin, the Sicilian Muses wept as the Fates took away, on the feast of St. Cecilia, Guillermus Hobrecht, adorned with great probity, who travelled through the Sicilian shore; it is he, also, who begot the Orphic Jacob for the Muses: therefore sweetly sing this song, gentle choir of succentors, so that his soul may be carried to Heaven and be given the palm. ${ }^{15}$

Nearly $5^{\circ}$ years ago the historian Berten De Keyzer identified the Willem Obrecht mentioned in this text with one of the six men appointed in $145^{2}$ by the authorities in Ghent to serve as city trumpeters. ${ }^{16}$ Willem, then, was also a musician. Belonging to this small, permanent corps of civic trumpeters, as Wegman has recently demonstrated, brought with it certain rewards, both financial and social, and

13 Smijers, "Twee onbekende motetteksten"; see also idem, "Het Motet "Mille quingentis' van Jacob Obrecht," Tijdschrift van de vereniging voor nederlandse muziekgeschiedenis 16 (1942): 212-15. Inter praeclarissimas immediately precedes Mille quingentis in the Segovia manuscript.

${ }^{14}$ Wegman, Born for the Muses, 288-96.

15 The Latin text follows that provided in Leofranc Holford-Strevens's commentary to the text (hereafter Holford-Strevens, "Commentary"), published as part of Appendix I in Wegman, Born for the Muses, 368-70. The translation is from Wegman, Born for the Muses, 23. The only published edition of the motet to include its text is New Obrecht Edition, vol. 16, ed. Chris Maas (Utrecht: Koninklijke Vereniging voor Nederlandse Muziekgeschiedenis, 1996), 1-11; also published in Werken van Jacob Obrecht, vol. 6, ed. Johannes Wolf (19o8-21; repr. Farnborough: Gregg Press, 1968), 179-88 (no. 20, "Requiem aeternam").

${ }_{16}$ Berten De Keyzer, "Jacob Obrecht en zijn vader Willem: De Gentse relaties," Mens en Melodie 8 (1953): 31 7-19. 
Willem appears to have served honorably in this capacity from $145^{2}$ until his death in $1488 .{ }^{17}$ Still, it is hardly to be expected that his passing would have occasioned the types of literary or musical tributes most often reserved for important political and ecclesiastical figures. And yet this is precisely what we have in Mille quingentis-Requiem aeternam, a large-scale cantus firmus motet that in its general features resembles other ceremonial and commemorative motets of the period. ${ }^{18}$ Moreover, in its use of a chant drawn from the Mass for the Dead the work

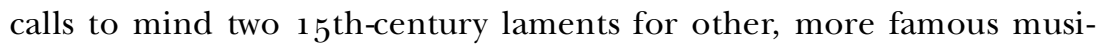
cians: Johannes Ockeghem's Mort tu as navré-Miserere (for Binchois, d. Sept. 1460), and Josquin's Nymphes des bois-Requiem aeternam (for Ockeghem, d. Feb. 1497). In at least one significant respect, of course, Mille quingentis stands apart from these other musical commemorations; for although Ockeghem, in his lament for Binchois, referred to the older composer as le père de joyeuseté, and Josquin in turn mourned the death of Ockeghem, nostre maître et bon père, only Obrecht's motet was written in response to the loss of a biological father.

It is this obviously personal connection that has predisposed scholars to study the motet as a potential source of biographical information on the composer, his father, or both. As a result, ever since Smijers's

1941 article Mille quingentis has been at the center of all scholarship concerning the composer's life. Indeed, perhaps no other single work by him has been the object of more commentary and speculation, much of it driven by a belief that these eight lines of poetry, in Wegman's words, "hold the key to Jacob Obrecht's origins."19 Until quite

${ }_{17}$ For the fullest account of what is known of Willem's life and career see Wegman, Born for the Muses, 22-69, 147-56, with the results of further archival research on the Obrecht family provided in idem, "Agricola, Bordon and Obrecht in Ghent: Discoveries and Revisions," Revue belge de musicologie $5^{1}$ (1997): 23-62.

18 Wegman, Born for the Muses, 24, notes similarities between Mille quingentis and Johannes de Sarto's motet Romanorum rex, "a work that uses the same tenor as Obrecht's motet, and treats it in similar fashion, in a lament for Albrecht II, King of the Romans, who died in 1439." In many ways the music of Mille quingentis is as remarkable as its text, though the latter has tended to overshadow the former in almost all discussions of the work. I plan to address more fully the musical features of this and other motets by Obrecht in a future study.

19 Wegman, Born for the Muses, 21. Several articles published in the 1950 os attempt to tease biographical data from the text: Anny Piscaer, "Jacob Obrecht: Geboortedatum en andere bijzonderheden," Mens en Melodie 7 (1952): 329-33; De Keyzer, "Jacob Obrecht en zijn vader"; Bain Murray, "New Light on Jacob Obrecht's Development-A Biographical Study," The Musical Quarterly 43 (1957): 500-16; idem, "Jacob Obrecht's Connection with the Church of Our Lady in Antwerp," Revue belge de musicologie 11 (1957): 125-33. More recent discussions of the biographical implications of the text are Sister Mary Ellen Nagle, "The Structural Role of the Cantus Firmus in the Motets of Jacob Obrecht" (Ph.D. diss., Univ. of Michigan, 1972), 187-89 (with an English trans. of Smijers's emended version of the Latin text); Martin Picker, Johannes Ockeghem and Jacob Obrecht: A Guide to Research (New York: Garland, 1988), 39-41 (with another English trans., also based on 
recently these origins were defined in the narrowest of terms-date and place of birth. In his influential interpretation of the poem, Smijers, setting what now seems an unfortunate precedent, construed (and emended) the Latin text in such a way as to understand the date mentioned in line 5, 22 November ("Cecilie ad festum"), as referring not to Willem's death, but rather to Jacob's birth. ${ }^{20}$ This interpretation of the date figured in all subsequent discussions up through the late 1980 s. $^{21}$ Even more far-reaching in its effects was Smijers's reading of lines 5 and 6 as a whole, which he gave as Caeciliae ad festum, qui Siciliam peragravit, I Coram idem Orphei cum Musis Jacobum generavit. Among the several changes he made to the text the most important was his silent changing of Segovia's oram to coram, thereby beginning a new sense unit at this point. On this reading, then, Willem, who traveled through Sicily, had a son on the feast of St. Cecilia in the presence of Orpheus and the Muses. Smijers suggested that the text could be taken to mean that Jacob had been born in Sicily while his father was travelling there, and that in any case Willem had spent some time in Sicily. Even while noting, without further comment, that line 3 of the poem incorporates two quotes from Vergil's Fourth and Fifth Eclogues, Smijers proposed that 414 one of these, Sicilides flerunt Musae, was perhaps an indication that Willem had died in Sicily. ${ }^{22}$

In the 195os, Anny Piscaer and Bain Murray, following the basic outlines of Smijers's interpretation, attempted to use the text to determine more precisely Obrecht's date and place of birth. It was also during these years that the idea that Willem Obrecht had literally "travelled through Sicily" first came to be widely accepted. Piscaer, writing the year before De Keyzer identified Willem as the trumpeter in Ghent, argued that the occasion for Willem's trip to Sicily could have been as a member of the company that traveled with the Marquis Henryk of Bergen op Zoom on a pilgrimage to the Holy Land in $145^{\circ}$. On the basis of this speculation she claimed that in the Mille quingentis text Jacob was recalling the conjunction of his father's trip and his own birth. Thus, she claimed, Jacob was born in Bergen op Zoom on 22 November $145^{\circ}$, his pregnant mother presumably unable to accompany her

Smijers's version); Rob C. Wegman, "Music and Musicians at the Guild of Our Lady in Bergen Op Zoom, c. 1470-1 $5^{10}$," Earlv Music History 9 (1989): 175-249, at 198-201; Reinhard Strohm, The Rise of European Music, I380-I5 Oo (Cambridge: Cambridge Univ. Press, 1993), 487-88; Wegman, Born for the Muses, 12-13, 21-24, 46-47, 67-69, 15 o, 368-70 (= Holford-Strevens, "Commentary").

2o Smijers, "Twee onbekende motetteksten," $133-34$.

2122 November is still given as Jacob Obrecht's birthdate in Picker, "Johannes Ockeghem," 4 o.

${ }_{22}$ Smijers, "Twee onbekende motetteksten," 134. 
husband on the arduous trip. ${ }^{23}$ Bain Murray questioned the basis for Piscaer's argument-and rightly so, since the documentation relating to Hendryk's pilgrimage nowhere makes mention of Willem Obrecht. Aware of De Keyzer's archival findings in Ghent, Murray wondered whether Willem might have originally come from Bergen op Zoom and settled in Ghent only in $145^{2}$, after his voyage to Sicily. As with previous commentators on Mille quingentis, there was no question for Murray that the text refers to an actual trip: the poem, he claimed, "tells us that Jacob must have been born before this date [i.e., 1452], for his birth took place while William [sic] was still in Sicily." ${ }_{4}$

Reinhard Strohm appears to have been the first to raise questions about certain aspects of this interpretation. Given that the poem is an epitaph for Willem, he rightly notes that it was "unwise to expect it to reveal information on the place and date of birth of Willem's sonwhen does an epitaph give such information?"25 Yet even while recognizing that the poem fits (more or less) within a particular genre and that 22 November refers to Willem's death rather than Jacob's birth, he nevertheless maintains that the text should be understood as alluding to a journey by Willem: "It probably means that Willem died on the feast of St. Cecilia's Day (whose name is juxtaposed with that of Sicily, for the sake of the pun), while on a trip in Sicily; alternatively the trip may only be mentioned as a memorable event of his life, and not in connection with the date." ${ }^{26}$ Strohm's observation concerning the verbal play on Cecilie / Ceciliam is important as a way of orienting oneself to the semantic field of the poem as a whole, and this particular verbal association extends as well to the Sicilian Muses referred to in line 3, a point to which I will return. It should be mentioned that Strohm, too, emends the text, and at the same spot that Smijers had. Instead of "coram," however, he proposes "os" as the first word of line 6, which he then translates: "He begat with the Muses Jacob, the mouth of Orpheus." Inasmuch as the Segovia manuscript unambiguously shows "oram," it is difficult to see the justification for altering the text at this point (except perhaps to avoid an enjambment over the rhyme: qui Siciliam peragravit I Oram). At all events, it is indicative of certain problems inherent in a literalist reading of the poem that the passage scholars have emended most is that which has prompted the most disagreement in terms of its interpretation.

23 Piscaer, "Jacob Obrecht: Geboortedatum," 329-30.

${ }^{24}$ Murray, "New Light," 501.

${ }_{25}$ Strohm, The Rise, 487.

${ }_{26}$ Ibid., 488. 
Leofranc Holford-Strevens has recently demonstrated that such emendations are probably unnecessary and that the most plausible version of the text is one that conforms closely to that given in the manuscript. In a brief, but characteristically insightful commentary he notes, among other things, that for some of the poem's metrical features (including the enjambment just mentioned) precedents exist in Vergil's Aeneid. ${ }^{27}$ Perhaps most important, he has established the best reading of the poem to date, one that has at last set a solid textual foundation for its interpretation. Holford-Strevens's commentary appears as an appendix in Rob Wegman's recent book on the life and Masses of Obrecht, where an extended and thoughtful discussion of Mille quingentis offers the most persuasive case yet for a literalist reading of some of its problematic passages. ${ }^{28}$ Wegman draws attention to the use of figurative language in the poem, but, like Strohm, he then attempts to explain the phrase qui Ceciliam peragravit oram as referring to an actual trip made by Willem. Citing the strengthened political ties between Burgundy and Naples in the early $147 \mathrm{Os}$, he notes that the first chamberlain of the Burgundian court, Antoine of Burgundy, was sent to Naples in 1475 to notify King Ferrante of his election to the Order of the 416 Golden Fleece. Wegman believes that such an important official embassy would have included musical forces, and that the Ghent city magistrates might well have lent out their trumpeters, including Willem, for this trip. He goes on to say that Jacob, in writing Mille quingentis, "might truthfully have described Naples, the residence of the king of Sicily, as 'the Sicilian shore'." 29 While no detailed documentation of this journey has come to light, Wegman's broader point is well taken; namely, that the plausibility of this scenario is perhaps more important than whether it can be documented. As he puts it, "it would have been typical of Willem's life and career if he had travelled with Antoine of Burgundy to Naples. And this typical pattern, of his professional status and political allegiance, suggests a multitude of other, undocumented possibilities and opportunities, not only for him but also for his son."3o

The recognition of such patterns is important-and clearly quite useful in the absence of documentation-for gaining a better sense of the Obrechts' careers. Viewing the poem in this way, however, has the odd effect of making Willem's trip-real or potential-seem much less significant in either of their lives, which raises the question of why Jacob chose to mention it so prominently in what might well have been the last "public" words he would ever write about his father. Why is

27 Holford-Strevens, "Commentary," 368-70.

${ }_{28}$ Wegman, Born for the Muses, vii, 12-13, 21-25, 46-47, 67-69, 15 o.

29 Ibid., 68-69.

$3^{\circ}$ Ibid., 69 . 
Willem said to have travelled the Sicilian shore? And why did the Sicilian Muses weep as the Fates took him away? Behind these questions stands another: is there a way of understanding the poem that more accurately reflects the sensibilities and mental habits of people living (and dying) in the later $15^{\text {th }}$ century?

Before turning to the text and a fresh consideration of its background sources, a few words need to be said on the issue of authorship. Previous writers have reasonably assumed that both the poem's subject matter and its striking-even extravagant-reference to the composer (the Orphic Jacob, begot for the Muses) point to Obrecht as author of the text. The existence of another autobiographical motet, Inter praeclarissimas virtutes, the prose text of which also highlights the composer's name, would seem to offer support for this assumption. There are in addition the similarly self-referential works by a number of other composers active in the $15^{\text {th }}$ century (Ciconia, Du Fay, Busnoys, Josquin). If in some of these cases the composer's authorship of the text seems difficult to deny (e.g., Busnoys's Anthoni usque limina and perhaps Josquin's Illibata Dei virgo nutrix), the evidence for most of the others is less compelling. And to be fair, Mille quingentis could be seen as belonging to this latter group. In theory at least, Obrecht could have commissioned someone else to write this poem commemorating his father. Certainly by the late $15^{\text {th }}$ century the commissioning of literary epitaphs for one's relatives was not uncommon, nor necessarily limited to the exalted. Examples of formal verse epitaphs (complete with classical allusions) for individuals of relatively modest status can be found even among the writings of renowned authors; sometimes in such cases the dedicatee of the poem was a friend or acquaintance of the writer. ${ }^{3}$ We should also recognize the possibility of some kind of joint

$3^{1}$ Erasmus, for example, composed two short epitaphs (ten and thirty-two verses, respectively) in 1490 for one Berta van Heyen, who in her last years was head-mother of the hospital of St. Elizabeth in Gouda. She is known to have invited Erasmus and other monks to her home on numerous occasions. Both epitaphs contain quotations and allusions to classical poetry, especially the second, which cites Vergil's Eclogues and Aeneid, various works by Horace, and a hymn by the Christian poet Prudentius (fl. 4oo C.E.). Another of his epitaphs, written probably ca. 1497-99, is for the otherwise unknown Margaret Honora, apparently commissioned by her husband. Again, in the course of a mere eight verses the poem quotes or paraphrases the Aeneid in several places, as well as Ovid's Ars amatoria; see Collected Works of Erasmus, vols. $8_{5}$ and 86, ed. Harry Vredeveld, trans. Clarence H. Miller (Toronto: Univ. of Toronto Press, 1993), 85: $5^{8-59}, 330-33$; 86 : $47 \mathrm{O}-71,687-89$. A personal acquaintance between poet and dedicatee can be assumed also in the case of the four epitaphs for Johannes Ockeghem written probably in the late 1460 (when the composer was still very much alive) by Petrus Paulus Senilis, a French humanist who served as a secretary of King Louis XI; see Reinhard Strohm, " Hic miros cecinit cantus, nova scripta reliquit'," in Johannes Ockeghem: Actes du XL ${ }^{e}$ Colloque international d'études humanistes, ed. Philippe Vendrix (Paris: Klincksieck, 1998), 139-65. As Strohm notes, Senilis presumably expected that Ockeghem "would appreciate the particular, humanist style of his texts, and that he would be aware of classical precedent for such 'prehumous' epitaphs." 
authorship, whereby Obrecht, with perhaps some general ideas for the poem in mind, would have consulted with someone more accustomed to writing such texts. Here though the poem's reference to the "Orphic Jacob" is significant and would seem to carry even greater evidentiary weight than has been supposed. Verse epitaphs have always depended heavily on formulas. The nature of these formulas could and did change over time, if slowly. However, from the terse funerary inscriptions of the early Middle Ages through to the classically-inspired humanistic epitaphs increasingly common from the 143 os, there appears to be no real precedent for placing such emphasis as we find in Mille quingentis on the name and attributes of the dedicator of the epitaph. Praise and compliment were quite naturally reserved for the dedicatee, the deceased, while the name of the dedicator, when present at all, was usually given without elaboration. $3^{2}$ It is difficult to imagine anyone commissioned to write such a text (and thus presumably familiar with the genre) violating this convention so thoroughly. However one interprets the phrase Orpheicum Musis Jacobum generavit, its very presence in Mille quingentis seems to make Obrecht's authorship exceedingly likely, and anyone else's equally unlikely.

418 Still, the nagging doubts that sometimes hover around such questions of authorship concern not only degrees of certainty. Much has been invested in all these putative textual attributions, leaving discussions of them at times open to the criticism of reinforcing an authorcentered approach to music history and its concomitant limitations (actual or potential). At the same time, these provisional attributions (and almost all are necessarily so) have opened, not closed, many fruitful lines of inquiry, prompting scholars to form richer images of individual composers and their engagements with contemporary social, religious, literary, and institutional practices. Du Fay the supplicant, as reflected in the troped text of his Ave regina coelorum (III), or Busnoys the anxious penitent weaving his name into the words of Anthoni usque liminathe heuristic value of such texts stems partly from their authorial status. 33 Their self-referential nature provides a starting point for the consideration of how these works open out onto the world in which they were written. Given its plausibility, positing Obrecht's authorship of Mille quingentis offers a similar opportunity.

$3^{2}$ On these conventions in epitaphs, see Iiro Kajanto, Classical and Christian: Studies in the Latin Epitaphs of Medieval and Renaissance Rome, Suomalaisen Tiedeakatemian Toimituksia, ser. B, vol. 203 (Helsinki: Suomalainen Tiedakatemia, 1980), 1 7-19.

33 Alejandro E. Planchart, "Notes on Guillaume Du Fay's Last Works," Iournal of Musicology 13 (1995): 55-72; Rob C. Wegman, "For Whom the Bell Tolls: Reading and Hearing Busnoys's Anthoni usque limina," in Hearing the Motet: Essays on the Motet of the Middle Ages and Renaissance, ed. Dolores Pesce (New York: Oxford Univ. Press, 1997), $122-41$. 


\section{Obrecht's Anchises}

The most conspicuous feature of the poem as a whole is its hybrid nature. While in many respects indebted to the medieval tradition of verse epitaphs, in other ways the text betrays its author's awareness of the classicizing tendencies of fifteenth-century humanistic poetry. It is not simply that he has written "classical" hexameters that consistently employ "unclassical" rhyme (this being common practice among medieval writers who chose to use this meter);34 rather, the poem's peculiar mixture of medieval and humanistic elements arises from the variety of textual types, allegorical traditions and poetic techniques on which it draws. Recognition of this patchwork of sources helps place in relief the chain of associations and allusions at work in the poem.

Lines 1 and 2 comprise an elaborate indication of the year of Willem's death: Mille quingentis verum bis sex minus annis I Virgine progeniti lapsis ab origine Christi ("After fifteen hundred less twice six years had lapsed since the birth of Christ, Son of the Virgin"). The inventiveness of this formulation, beyond setting an elevated tone, immediately situates the text within a particular register of commemorative poetry, namely, the memorial verses found in many medieval historical chronicles. These short poems, appended to the chronicler's usually bare record of noteworthy events that occurred in a given year (and often added long after the initial copying of a manuscript) serve to highlight entries of special importance-military victories, the deaths of rulers, and natural disasters being preferred topics. Hundreds of examples have been identified in chronicles from the Carolingian period on, and a very large number of these devote their first line or two to indicating the year in question. Most are a good deal more straightforward than the opening of Mille quingentis, though even in such cases the formulas are often not unlike Obrecht's:

Millenis quadringentenis uno minus anno . . . (= a. 1399)
Anno milleno trecentis bis minus anno ... (= a. 1 298)
Millenisque trecentenis sed sex minus annis . . (= a. 1294)35

34 On the frequent use of rhyme in hexameters among writers from the ninth to the fourteenth centuries, see Dag Norberg, Introduction à l'étude de la versification latine médiévale (Stockholm: Almqvist \& Wiksell, 1958), $65^{-69}$.

35 The opening lines of more than two hundred such poems are given in Hermann Oesterley, "Denkverse bei mittelalterlichen Geschichtsschreibern," Forschungen zur deutschen Geschichte 18 (1878): 19-45; the examples cited are nos. 175, 73, and 177. Further examples of the genre are cited in Hans Walther, Initia carminum ac versum medii aevi posterioris latinorum, 2nd ed. (Göttingen: Vandenhoeck \& Ruprecht, 1969), esp. nos. 11033-11060; for examples from the early Middle Ages see Dieter Schaller and Ewald Könsgen, eds., Initia carminum Latinorum saeculo undecimo antiquiorum (Göttingen: Vandenhoeck \& Ruprecht, 1977). 
That this type of memorial verse served as a model (conscious or otherwise) for the motet's opening lines is particularly apparent from those examples that mention Christ and the Virgin:

Virginis a partu, Domini qui contigit ortu,

Anno milleno centeno minus et uno ... (= a. 1099)

Anno quo Christus de virgine natus, ab illo

Transierunt mille decies sex tresque subinde . . (= a. 1o63) $)^{3^{6}}$

A seven-line epitaph for Emperor Charles IV (d. 1378) is typical in many ways of the genre:

Mille trecentis octo post septuaginta

Annis verbigene decessit ter Ka. Decembris

Cezar magnificus Karolus pius, ordine quartus.

Princeps invictus fuit, iam sub rupe sepultus,

Sensu non pugna qui subdidit sibi regna

Rexque Bohemorum fuit hic et serra malorum.

Ut Deus in celis locet hunc, pete quisque fidelis. 37

Calculating the date from "Him who was begotten of the Word" (verbigene), the poem presents the structure and standard elements of a medieval verse epitaph: the name of the deceased; his or her rank or profession (here given somewhat expanded treatment, commensurate with the Emperor's status); the common expressions of the deceased's virtue (pius); the different fates of body and soul after death, with the former confined to earth (sub rupe sepultus), the latter to ascend to heaven (for which the faithful are to pray) $.3^{8}$

Several of these standard features also appear in Mille quingentis. In addition to the formulaic date given at the opening, line 4 of the text (with the beginning of line 5), Hobreht Guillermum, magna probitate decorum I Cecilie ad festum, names the deceased (but not his profession), provides the date on which he died, and praises his moral integrity and uprightness (probitas, a stock epithet in later $15^{\text {th-century epigraphy }}$

$3^{6}$ The first poem cited records the taking of Jerusalem during the First Crusade; see Annales Elnonenses, ed. Georg Heinrich Pertz, Monumenta Germaniae Historica, Scriptores 5 (Berlin, 1844), 14. For the second poem see Oesterley, "Denkverse," no. 82.

37 The poem was copied in the late $14^{\text {th }}$ century into a $13^{\text {th-century manuscript of }}$ Martin von Troppau's Chronicon Pontificum et Imperatorum; Monumenta Germaniae Historica, Scriptores 22 (Berlin, 1872 ), 388.

$3^{8}$ On these typical features as they occur in medieval funerary inscriptions, see Kajanto, Classical and Christian, 1 7-18, 57-75. 
though, interestingly, apparently little used before that time). ${ }^{39}$ Lines 7 and 8 address the "gentle choir of succentors," asking that they sing this motet for the benefit of Willem's soul, that it "be carried to Heaven and be given the palm" (data palme).4 $4^{\circ}$ Taken together, these conventional features provide an overall framework for the poem. It is all the more striking then to see how Obrecht departs from these poetic conventions, and to what effect.

The first of these departures comes in line 3, where medieval memorial gives way to the poetry of Vergil. Sicilides flerunt Muse, dum fata tulerunt is not an integral line from Vergil, as the unclassical use of rhyme between caesura and line-end (flerunt-tulerunt) makes clear.4 ${ }^{1}$ Rather, it is a centonate verse, made up from partial lines taken from two of Vergil's Eclogues and combined in such a way as to create a "new" credible verse. Sicelides Musae are the opening words of his Eclogue 4, by a wide margin the most famous of Vergil's shorter poems. In an exegetical tradition stretching back to the $4^{\text {th }}$ century, the poem (often called the "Messianic eclogue") was believed to foretell the birth of Christ. Couched in the vague language of Sibylline prophecy, passages in the poem readily lent themselves to such an interpretation. Particular significance was attached to lines $4-7$, which predict the birth of a divine child to the Virgin, an event that will usher in the return of a golden age:

39 In his survey of medieval and Renaissance Roman epitaphs, Kajanto notes that of the many inscriptions that employ the word probitas the earliest dates from 1462 . The term appears less frequently in Roman epitaphs than do its near synonyms fides and integritas. Kajanto notes that all three concepts were treated as "aristocratic virtues," with the one distinction among them being that probitas "seems to belong to the private rather than to the public sphere of life." See his Classical and Christian, 113-17. Though used by classical authors (frequently in the letters and speeches of Cicero), probitas does not appear in Vergil's works and seems not to have figured in the poetic register of the language.

$4^{\circ}$ Holford-Strevens, "Commentary," 370 notes the poetic inversion employed here (literally the phrase means "the soul is to be given to the palm") and the classical precedents for it, citing Aen. 3.61 dare classibus Austros. Partly on the basis of its last two lines, Wegman plausibly suggests that the motet may have been intended for annual services for Willem: "Jacob's prominence in the text may indicate that he endowed the commemoration service on behalf of his father. His motet could then be the musical equivalent of an endowment contract, its basic message being that Jacob, son of Willem Obrecht, orders a motet in polyphony to be sung in perpetuity on the day of his father's death, 22 November" (Born for the Muses, 24). On this account, the text reflects on itself and on the motet's function within social and religious practices of the time; all the more reason then to examine the language of the text in terms of how it reflects and embodies contemporary modes of poetic commemoration.

$4^{1}$ This rhyme pattern occurs in 11. 1-4, though only that in 1.4 is disyllabic. Lines $5^{-8}$ comprise two couplets, with pairs of verses exhibiting rhyme both at the caesura ( festum-Orpheicum) and at line-end (peragravit-generavit). For these and other observations on language and versification see Holford-Strevens, "Commentary," 369-70. 
Ultima Cumaei venit iam carminus aetas; magnus ab integro saeclorum nascitur ordo. iam redit et Virgo, redeunt Saturnia regna, iam nova progenies caelo demittitur alto. $4^{2}$

The first of Vergil's poems to be Christianized in this way, Eclogue 4 offered medieval writers their strongest justification for claiming him as a prophet, one who could even be mentioned in the same breath as Isaiah.43 Vergil's status as the preeminent author of Latin antiquity clearly fueled the desire among patristic writers to reconcile his poetry with the teachings of the Church.44

It should be stressed that this Christian reading of Eclogue 4, though in large measure forged in the literary and exegetical traditions of late antiquity, spread in subsequent centuries well beyond the domain of learned commentaries. At least in its basic outlines the prophetic reading of Vergil's poem circulated widely and in a variety of cultural registers. Thus we find relevant passages of the poem quoted or paraphrased in an 11 th-century metrical epitaph;45 in the quadruplum of a

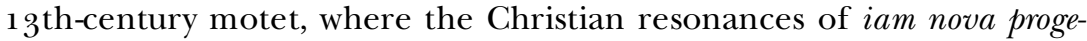
nies underlie the complex connections among the motet's various

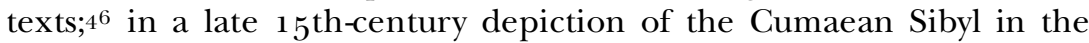
pavement of Siena Cathedral, accompanied by the prophetic lines $4-7$ of Eclogue 4, with both poem and author explicitly cited; 47 and of

$4^{2}$ Ecl. $4 \cdot 4-7$.

43 In at least one French illuminated psalter from the $13^{\text {th }}$ century, a Tree of Jesse figure includes Vergil among the prophets, with a banderole reading Jam nova progenies; Emile Mâle, "Virgile dans l'art du moyen âge français," Studi Medievali 5 (1932): 325 $5^{-31}$.

44 The best discussion of Christian interpretations of Eclogue 4 from the Church Fathers through to Abelard remains Pierre Courcelle, "Les Exégèses chrétiennes de la quatrième Églogue," Revue des études anciennes 59 (1957): 294-31 9; see also the important survey of this interpretive tradition in Stephen Benko, "Virgil's Fourth Eclogue in Christian Interpretation," Aufstieg und Niedergang der römischen Welt, II.31.1, ed. Wolfgang Haase (1980), 646-705. It should be noted that not all the Latin fathers shared this desire. Jerome in particular seems to have resisted the idea of interpreting either Eclogue 4 or passages from the Aeneid in a Christian light; Courcelle, "Les Exégèses," 309-11. On the significance of the Fourth Eclogue within the medieval tradition of interpreting Vergil as poeta theologus, and the $15^{\text {th-century refinements of this idea, see Kallendorf, Virgil and the }}$ Myth of Venice, $95^{-1} 10$.

45 Walther, Initia carminum, no. 11503 . The first of the epitaph's 35 verses paraphrases the opening line of Ecl. 4, with Vergil's Sicelides Musae, paulo maiora canamus becoming Musa, melos resona paulo majora canendo.

$4^{6}$ Sylvia Huot, Allegorical Play in the Old French Motet: The Sacred and the Profane in Thirteenth-Century Polyphony (Stanford: Stanford Univ. Press, 1997), 11 5-27. The motet is In salvatoris nomine / Ce fu en tres douz tens de mai / In veritate comperi / Veritatem. Ecl. 4.7 is paraphrased as Iam nova progenies | Dilabitur | Et mittitur | A supreme celo.

47 A photograph of this remarkable Sibyl pavement appears in Enciclopedia Vergiliana (Rome, 1984-91), vol. 1, 581. An early 16th-century wooden relief in the choir of 
course in that richest testament to Vergil's influence on medieval eschatology, Dante's Commedia, in which at one point the poet Statius (ca. 40-95/96 C.E.), addressing Vergil, quotes lines $5^{-7}$ of the Eclogue (in Italian), implying that the poem converted him to Christianity. ${ }^{8}$ Examples of this Christian "naturalization" of the text could be multiplied many times over. 49

Fata tulerunt, the other Vergilian element in line 3 of Mille quingentis, comes from Eclogue 5.34: tu decus omne tuis. postquam te fata tulerunt, I ipsa Pales agros atque ipse reliquit Apollo ("So you were all grace to your people. When the Fates bore you off, Pales herself, Apollo himself left the land"). $5^{\circ}$ This is the only use of the phrase in Vergil's works, in the one Eclogue that deals most explicitly with death and resurrection, specifically the death of Daphnis. The classical idea that linked the Fates to death, however incompatible with certain fundamental Christian beliefs, occurred frequently in post-classical epitaphs of all sorts, and from the $15^{\text {th }}$ century various forms of the tag fata tulerunt found their way into much humanistic poetry. Humanists also followed Vergil's precedent in placing the phrase at the end of a verse (as happens also in Mille quingentis) $.5^{1}$

the cathedral of Zamora depicts Vergil holding a book and a scroll on which one can see the word progenies; the inscription below the figure reads Vergilius Bucol 4; see Luigi Suttina, "L'effigie di Virgilio nella cattedrale di Zamora," Studi Medievali 5 (1932): 342-44. Kallendorf, Virgil and the Myth of Venice, 103, mentions the Siena pavement and notes that the prophetic interpretation of this poem lived on well past the Renaissance, as in the case of Alexander Pope's Messiah: A Sacred Eclogue Composed of Several Passages of Isaiah the Prophet, Written in Imitation of Virgil's Pollio of 1712 (Vergil addressed Ecl. 4 to the consul Asinius Pollio).

$4^{8}$ Purgatorio 22.67-73: "Facesti come quei che va di notte, I che porta il lume dietro e sé non giova, I ma dopo sé fa le persone dotte, I quando dicesti: 'Secol si rinova; I torna giustizia e primo tempo umano, I e progenie scende da ciel nova'. I Per te poeta fui, per te cristiano"; La Divina Commedia, ed. Natalino Sapegno, vol. 2 (Florence: La Nuova Italia Editrice, 1980), 245; The Divine Comedy. Purgatorio. Text and Commentary, ed. and trans. Charles S. Singleton (Princeton: Princeton Univ. Press, 1973), 238-39.

49 A further development in this process occurred in 16 th-century France, where the Christianized interpretation of the poem took on strongly political overtones; Pierre de Ronsard's First Eclogue (from his Eclogues et mascarades, written 1563-4) draws on the theme of the puer nascens of Vergil's poem in a panegyric for Charles IX. On this and other examples see Agnes Becherer, "Die panegyrische Inszenierung des Herrschens in der französischen Literatur der Renaissance-Versepos und Eklogendichtung," in Tradita et inventa: Beiträge zur Rezeption der Antike, ed. Manuel Baumbach (Heidelberg: Universitätsverlag C. Winter, 200o), 131-46.

$5^{\circ}$ Trans. after M. Owen Lee, Death and Rebirth in Virgil's Arcadia (Albany: State Univ. of New York Press, 1989), 91. The only previous mention of this quotation in the literature on Mille quingentis is Smijers, "Twee onbekende motetteksten," 134, where it is noted without further comment.

$5^{11}$ Two examples will suffice. Michele Marullo (after $1453^{-1} 5^{\circ 0}$ ), the accomplished poet active first in Naples (in the circle of writers around Pontano) then later in Florence, manages to incorporate fata tulerunt twice at line-ends (the second time altered 
For about 18 centuries Vergil occupied a central place in the Western imagination. Owing to what now must seem an often astonishing familiarity with his poetry-inculcated through its use in education at all levels-writers could quote, paraphrase, or allude to his writings in a variety of ways and for a multitude of purposes. Though certain very accomplished poets occasionally balked at a focus on Vergil that risked the neglect of other great figures, for the most part writers (perhaps especially those of humbler gifts) seem to have recognized the boon of such a vast thematic and lexical reservoir on which to draw. $5^{2}$ Certainly many put it to use at one time or another. As a result, in trying to assess the significance of a particular Vergilian theme or turn of phrase, especially where a writer of relatively minor abilities is concerned, one should leave open the possibility that he or she was, at one level, simply taking advantage of cultural practices that had helped ensure the continued existence in many readers' minds of a web of literary and historical references. Such might have been the case with Obrecht's use of fata tulerunt. The general nature of the phrase, and thus the ease with which it could be fitted into any appropriate poem in hexameters, made it something of a poetic commonplace. Moreover, mention of the Fates 424 brought with it an intrinsic association with death, one that did not necessarily depend for its effect on the phrase's function within its original Vergilian context.

It is hard, however, to account in this way for Obrecht's third verse as a whole. Two issues here require closer consideration. First, there is the line's centonate construction (a technique not used elsewhere in the poem) and the medieval association of this practice with Vergil's works. A second, related issue concerns the line's other obvious citation of Vergil, Sicilides . . Muse, and how the choice of this particular phrase may have been prompted by the various functions it could serve within the poem's meshed sequence of associations.

to fata inimica tulerunt) in the course of a 30 -line lament for his brother; An Anthology of Neo-Latin Poetry, ed. and trans. Fred J. Nichols (New Haven: Yale Univ. Press, 1979), 227-28. Pietro Bembo (1470-1547) concludes his lament on the death of Poliziano with the lines Heu, sic tu raptus, sic te mala fata tulerunt, I arbiter Ausoniae, Politiane, lyrae! (with the sic / sic construction echoing the scene of Dido's death; cf. Aen. 4.66o); Renaissance Latin Verse. An Anthology, compiled and ed. Alessandro Perosa and John Sparrow (Chapel Hill: Univ. of North Carolina Press, 1979), $171-72$.

$5^{2}$ It is telling that Jacopo Sannazaro $\left(145^{6-1} 530\right.$ ), one of the truly "Vergilian" authors of his generation, should have criticized those who in his view slavishly imitated Vergil to the point of excluding other classical writers. In a 1521 letter to Antonio Seripando he calls such writers "ignoranti bestie" and caricatures their attitude: "Virgilio non lo dice, dunque non è latino, dunque non si trova, dunque non si pò usare? Molte cose non dice Virg. che le diceno li altri, e son bellissime." See Letter 53 in Iacobo Sannazaro: Opere volgari, ed. Alfredo Mauro, Scrittori d'Italia 220 (Bari, 1961), $3^{81}$. 
The practice of concocting entire poems, in some cases running to hundreds of verses, out of excerpts from preexisting works (often in half-line units, but also single words) originated in antiquity. In the Latin world these cento poems drew almost exclusively on the works of Vergil (the Aeneid and, to a lesser extent, his Eclogues and Georgics). Of particular importance to the reception of Vergil in the Middle Ages and later were the Christian centones vergiliani of late antiquity, and of these the earliest and by far most influential was that of the $4^{\text {th-century Ro- }}$ man poet Proba (ca. 322-77 C.E.). Her Vergil cento, written ca. 360, consists of 694 hexameters, all of them constructed from lines, halflines, and single words taken from Vergil's works. More remarkable even than the technical feat of forming meaningful verses in this way is the subject matter of her poem: after a brief introduction, in which she proclaims Vergil a prophet of Christ's coming, she proceeds to narrate a series of significant episodes from both the Old and New Testaments, ranging from the creation of the world to the ascension of Christ.53 We can see an example of her approach in the way she incorporates the "prophetic" passage of Eclogue 4 . Line 34 of her cento begins with the crucial phrase iam nova progenies (Ecl. 4.7$)$, to which she joins a half-line from the Aeneid, omnis quem credidit aetas (Aen. 7.68o), thus "Offspring now new, in whom every age believed." 54 Contrived as such verses may seem to modern eyes, the ingenuity of Proba's technique-including the combinatorial and mnemonic skills on which it depended-and her success in wholly Christianizing Vergil, endeared the work to grammarians and clerics through many centuries. An extensive and continuous manuscript tradition attests to the poem's popularity, as do the many prints of it published throughout Europe, beginning in the $147 \mathrm{Os}$ and stretching well into the following century. 55 Her cento offered writers of all sorts a peculiar kind of access to Vergil and, more importantly,

53 See Mario Spinelli, "Proba Petronia," in Enciclopedia Virgiliana. A critical edition of Proba's cento, with an index of Vergil's verses used by her, is in Poetae christiani minores, ed. Karl Schenkl, Corpum scriptorum ecclesiasticorum latinorum 16 (Vienna: F. Tempsky, 1888), 51 1-6o9, 628-34. Other editions are Patrologia latina, vol. 19 (Paris, 1846), cols. 801-18; Elizabeth A. Clark, The Golden Bough, the Oaken Cross: the Virgilian Cento of Faltonia Betitia Proba (Chico, Calif.: Scholar's Press, 1981).

54 This appears to be the earliest poetic use of iam nova progenies in a Christian context; Clark, The Golden Bough, 18; on Proba's use of the Fourth Eclogue see 171-81.

55 Spinelli, "Proba." The editio princeps was published in Venice in 1472; Poetae christiani, 522. In his De viris illustribus Isidor of Seville praised Proba's ingenuity (ingenium) but not her art (studium). Even so, he recognized that her cento had made her the only woman to be placed among the men of the church (femina inter viros ecclesiasticos idcirco posita sola, pro eo quod in laude Christi versata est, componens centonem de Christo Virgilianus coaptatum versiculis. Cujus quidem non miramur studium, sed laudamus ingenium); cited in Patrologia latina, vol. 19, col. 8o 1. 
a model of how to use his poetry in their own.$^{6}$ Simply put, for Obrecht, as for so many before and after him, Proba's poem would have been an obvious and convenient source from which to learn how to manipulate Vergil's hexameters in this fashion.

Other than its medieval rhyme, line 3 of Mille quingentis conforms in most ways to the Proban model, even if its dependence on Vergil's shorter poems, rather than his epic, is less common in her work. As we have seen, Obrecht's Sicilides ... Muse comes from the "Messianic eclogue," while fata tulerunt is from Eclogue 5 . It is reasonable to assume, then, that the remaining significant word in his verse, flerunt, stems also from Vergil (the extraction of isolated words from his poems being a common practice in cento verses). At first glance, a possible source for flerunt seems to be Eclogue 5 again. In verses 20-21 of the poem (thus, only a dozen or so lines before the appearance of fata tulerunt), the nymphs are said to have wept (flebant) at the death of Daphnis:

Extinctum Nymphae crudeli funere Daphnin

flebant vos coryli testes et flumina Nymphis

The nymphs wept for Daphnis when he died his cruel death (You hazels and rivers are witness for them) .57

Here we have the same verb, though in a different tense from that in the Obrecht. The change from flebant to flerunt might well have been prompted by the need to rhyme with tulerunt. On the other hand, jumping directly to this conclusion overlooks an interesting component of the cento tradition. While the exigencies of constructing full-scale Vergilian centones necessitated minor changes to the original text, those by Proba and others reveal a strong tendency to employ Vergil's words, where possible, in the grammatical forms in which they appear in his works. It was probably this "default" approach that in most instances motivated the extraction of single words from his texts. In this way the virtue of being faithful to Vergil's language brought with it the added pleasure of demonstrating one's comprehensive knowledge of his poetry. With this tendency in mind, another passage in Vergil-and an in-

$5^{6}$ For the truly learned the value of Proba's cento might not have extended much beyond their school years. Dante and the Bolognese professor of literature Giovanni de Virgilio, in exchanging letters cast as bucolic dialogues-replete with characters, quotes, and near-quotes from Vergil's Eclogues—display an easy, playful familiarity with their classical model. Though their writings obviously demonstrate a different order of poetic sophistication from that of Proba, both men might well have benefited from youthful study of her techniques. On their "bucolic" correspondence, see Konrad Krautter, Die Renaissance der Bukolik in der lateinischen Literatur des XIV. Jahrhunderts: von Dante bis Petrarca (Munich: Wilhelm Fink, 1983), 23-56.

57 Trans. Lee, Death and Rebirth, 90. 
triguing one-presents itself as the more likely source for flerunt. The word appears just once in all of Vergil's writings, in Book 4 of his Georgics, in a section concerning Orpheus. It comes in line 461 , in a passage describing how miserabilis Orpheus and the Dryads lamented Eurydice's death.

At chorus aequalis Dryadum clamore supremos implerunt montes; flerunt Rhodopeiae arces altaque Pangaea et Rhesi Mavortia tellus atque Getae atque Hebrus et Actias Orithyia. Ipse cava solans aegrum testudine amorem te, dulcis coniunx, te solo in litore secum, te veniente die, te decedente canebat.

The chorus of Dryads, of her age, filled with their cries the mountain tops; the summits of Rhodope wept, and lofty Pangaea, and Rhesus' land of Mars, and the Getae, and the Hebrus, and from the Attic cliffs, Orithyia; while he went solacing his bitter love with the hollow lyre, singing of you, sweet wife, alone on the shore by himself, singing of you, as the day arose, you, as the day declined..$^{8}$

I wish to set aside for the moment the complicated question of whether the "Orphic" context of this passage somehow relates to the composer's description of himself in Mille quingentis as "the Orphic Jacob." Tempting as this may be, the issue is best approached in connection with trying to understand what might have led Obrecht to this passage in the first place, something I address toward the end of this study.

Apart from the Vergil quotations themselves, the most striking thing about this line is its singularity of construction: no other line in Mille quingentis even remotely resembles a cento. On the contrary, this brief Vergilian patchwork, in its tone and style, stands in sharp contrast to the conventional features of the opening verses. While we can safely assume a professional poet of the day would have frowned on such a shift in style, it is precisely this stark juxtaposition, I would suggest, that points us to the several functions the verse could fulfill. The first and most fundamental of these functions would have been as a clearly recognizable Vergilian "marker." Given the strong tradition that linked the writing of Latin centonate verse with Vergil's poetry, the most efficient (even obvious) way of signaling in such a short poem the presence of "Vergil"-whether this was understood as reference to his auctoritas or actually to his poetry and its thematic associations-was to compose a single cento, bounded at both ends by identifiably Vergilian tags (Sicilides

${ }_{5}^{8}$ Vergil Georg. 4.46o-66; trans. adapted from Adam Parry, "The Idea of Art in Virgil's Georgics," Arethusa 5 (1972): $35^{-52}$, at $4^{8}$. 
...Muse and fata tulerunt). Moreover, beginning the line with a quote from Eclogue 4 could perhaps also serve a secondary function of alluding to the salient feature of Vergil's poem in its Christian interpretation-the birth of Christ to the Virgin-thereby underscoring the elaborate construction used to indicate the year in line 2 of the motet text (Virgine progeniti lapsis ab origine Christi). Interpreting the phrase as an allusion of this sort would seem to account for his otherwise surprising decision to specify Sicilian Muses, more often associated simply with pastoral poetry in general and its origins in the Idylls of the Sicilian poet Theocritus. As Holford-Strevens points out, "had the author simply required an ornamental epithet for Muse scanning $-\cup \cup-$ he ought to have used Pierides." 59

However this may be, there remains a problem with this proposed secondary function. While it was common, as we have seen, to quote Vergil's Fourth Eclogue as a way of simultaneously alluding to its Christian interpretation, this was almost always done by citing part or all of the "prophetic" passage in its lines $4-7$. The reasoning behind this is clear enough: a phrase such as iam nova progenies could spark Christian associations with an immediacy that, patently, reference to the "Sicilian Muses" could not match. ${ }^{6}$ If anything, these opening words, owing to their identification with pagan pastoral poetry, might have seemed illsuited for purposes of alluding to the birth of Christ. Are we left then with a carefully concocted Vergilian "marker" that marks nothing but itself, a poetic conceit, classical window dressing intended to raise the tone? Certainly countless examples are known of classical auctores employed in this way. But in this case there are two things that suggest a more substantive motivation for including this centonate line. First, the words Sicilides ... Muse are not the only reference in the motet to Sicily. Second, and more importantly, Sicily_both as a place and as a concept -figures prominently elsewhere in Vergil's poetry, most especially in his Aeneid.

The date of Willem Obrecht's death, the feast of St. Cecilia 1488, was the one presumably factual detail with which the author of Mille quingentis had to contend. ${ }^{61}$ As such it would have been a sensible point

59 Holford-Strevens, "Commentary," 369 .

6o In this regard it is indicative that neither Proba nor the other late-antique authors of Christian centones chose to incorporate these opening words of the Fourth Eclogue.

${ }^{61}$ One pauses at a musical son writing for a musical father who happens to have died on the feast of a saint so often associated with music. In fact, the record of his death in the Ghent accounts does not provide a precise date. Wegman makes a convincing case, however, for understanding the relevant documents as referring to an event on or near St. Cecilia's day (Born for the Muses, ${ }_{15}{ }^{\mathrm{On}_{5}}{ }^{6}$ ). While it seems unlikely that Obrecht would have deliberately altered his father's death date, we should perhaps leave open the 
from which to proceed in composing the text, particularly since presenting this information (and identifying the dedicatee) according to the conventions of medieval epitaphs provided a ready-made framework for the poem (lines 1-2, 4 and the beginning of 5 ). The issue then would have been how to go about filling out and ornamenting this skeletal structure. Looking at the finished poem, the crucial step appears to have been his decision to enrich the text by amplifying the reference to the saint's name through the use of homonyms or nearhomonyms. This is most clearly the case, as Strohm has noted, in lines 5 and 6: Cecilie ad festum, qui Ceciliam peragravit I Oram, where the juxtaposition of the Latin words for "Cecilia" and "Sicilian" takes advantage of a similarity in spelling common in medieval sources (in Old French both saint and island are Cecile) ${ }^{62}$ Other than this homonymic relation, there is no obvious motivation for linking Cecilia and Sicily (the island does not figure in her vita). Medieval commentators of classical texts frequently turned to homonyms and near-homonyms in support of fanciful etymologies and the allegorical readings these engendered. ${ }^{63}$ Though an important aspect of medieval epistemology, this etymological tradition appears not to bear directly on the pairing here of Cecilia and Sicily. One could view this as simple punning word play, but in such an interpretation the line becomes something of a gratuitous display, an oddly inappropriate gesture given the poem's commemorative purpose. After all, other than praising Willem's probity and noting that he fathered Jacob, the only thing the poem tells us about him is that he "travelled through the Sicilian shore," which is doubtless one of the reasons scholars have focused on the meaning of this enigmatic phrase. Both its highlighted placement at the heart of the text and its seemingly specific nature suggest that previous commentators were right to sense something significant in this line. In weighing the possible meanings of this Sicilian journey, however, the poem's first reference to Sicily should not be overlooked: Sicilides flerunt Muse signals the presence of Vergil's poetry, and with it the potential prominence of figurative language in

possibility that he knew only approximately when Willem had died and chose Cecilia's day for symbolic purposes. Barring evidence to the contrary we are left with the testimony of Willem's son in the form of this poem.

${ }_{22}$ Holford-Strevens, "Commentary," 369 .

${ }_{63}$ Thus Fulgentius (fl. early 6th century), in his allegorical Vergil commentary ( $E x-$ posito Virgilianae continentiae secundum philosophos moralis, 11. 472-75), explains the significance of Anchises's name through recourse to a Greek phrase: "Notice the name Anchises, for Anchises in Greek is ano scenon, that is, living in one's own land. There is one God, the Father, King of all, dwelling alone on high, who yet is revealed whenever the gift of knowledge points the way"; Leslie George Whitbread, Fulgentius the Mythographer (n.p.: Ohio State Univ. Press, 1971), 132. For the Latin text see Rudolf Helm, ed., Fabii Planciadis Fulgentii opera (Leipzig: Teubner, 1898 ), 102. 
Mille quingentis. Confirmation of this potential comes from turning back to the Aeneid and to the last journey together of Anchises and Aeneas.

In Book 3 of the Aeneid, set in Carthage, Aeneas recounts to Dido what has occurred during the years of wandering after he and his followers escaped the fall of Troy. This is in many ways Anchises's book: throughout the narration of the Trojans' long journey westward he is very much at the center of events, leading the group with Aeneas, and acting as guide and counselor to his son. In particular it is he, not Aeneas, who interprets divine omens and the prophetic statements of various oracles and seers they consult in the course of their voyaging. In the end he takes on something of the quality of a seer himself, the one who most actively attempts to understand the destiny of the Aeneadae. All of this contrasts sharply with the image of him presented in Book 2, where he is depicted as feeble, fatalistic, and reluctant to leave Troy. The emphasis on Anchises in Book 3 and the positive valuation of his role in their journey serve to heighten the effect of the book's concluding episodes, which are those most relevant to our motet text. ${ }^{6} 4$

Having previously been warned by the seer Helenus (3.410-432) not to sail between Scylla and Charibdis (i.e., the Straits of Messina), 430 the Trojans break off their first attempt to reach the western coast of Italy, arriving eventually on the eastern shore of Sicily near Mt. Etna (3.554-569). There they encounter Achaemenides, a Greek who had participated in the taking of Troy and is now stranded on the island. He begs them to put to sea, taking him with them, so as not to encounter the murderous cyclops Polyphemus. No sooner has he described the creature than it appears on a mountainside heading for the shore (3.590-675). They depart in terror and, again heeding Helenus's warning, direct their ships southward. As they make their way along the coast Achaemenides points out various places, retracing his own wanderings $(3.690-706)$. From the locations mentioned in the text it is possible to follow the course they take along the southern and western coasts of Sicily (see the map given in Figure 1):

Sicanio praetenta sinu iacet insula contra

Plemyrium undosum, nomen dixere priores

Ortygiam. Alpheum fama est huc Elidis amnem

occultas egisse vias subter mare, qui nunc

695

${ }^{6} 4$ The abrupt change in Book 3 in Vergil's characterization of Anchises has often been cited as one of several inconsistencies in this part of the poem. Though helpful in understanding the order in which Vergil might have written or ordered Books 1-3, the issue does not affect the present discussion.; see Robert B. Lloyd, "Aeneid III. A New Approach," American Iournal of Philology 78 (1957): 133-1 51; idem, "The Character of Anchises in the Aeneid," Transactions and Proceedings of the American Philological Association 88 (1957): 44-55. 
FIGURE 1. Anchises's last journey. The arrows mark the route taken by the Aeneadae along the Sicilian coast, as described in Aeneid 3.682-708.

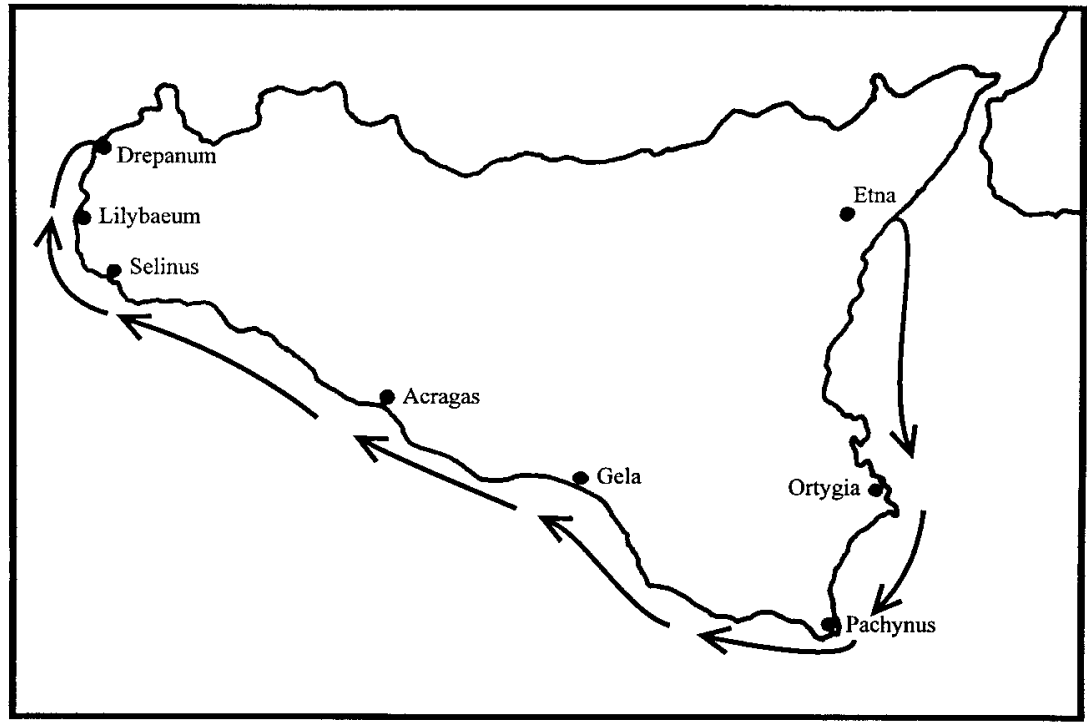

ore, Arethusa, tuo Siculis confunditur undis. iussi numina magna loci veneramur, et inde exsupero praepingue solum stagnantis Helori. hinc altas cautes proiectaque saxa Pachyni radimus, et fatis numquam concessa moveri 700 apparet Camerina procul campique Geloi, immanisque Gela fluvii cognomine dicta. arduus inde Acragas ostentat maxima longe moenia, magnanimum quondam generator equorum; teque datis linquo ventis, palmosa Selinus, et vada dura lego saxis Lilybeia caecis.

There's an island

Lying this side of a Sicilian bay,

Facing Plemyrium Point where the waves beat.

Early people called this isle Ortygia.

The tale runs that the Elean stream, Alpheus,

Took hidden channels there, under the sea, And through the fountain, Arethusa, now Infuses the salt waves. There, as directed, We worshipped the pure powers of the place, Then sailed on past Helorus' rich plowlands 
And ponds. We coasted high crags of Pachynus

With rocky tongues of land, and far away

Shone Camerina, never to be disturbed,

Then the Geloan Plain, Gela itself,

Named for a torrent; then beetling Acragas,

Breeder of mettlesome horses in the past,

Displayed her distant massive walls, and helped

By winds I put Selinus of the Palms

Behind us, to sail close to the shoal water

Of Lilybaeum with her hidden reefs.

Only upon reaching the northwest corner of the island do they make port, at Drepanum, at which point Anchises dies. Book 3 then closes with Aeneas's lament for his father:

hinc Drepani me portus et inlaetabilis ora accipit. hic pelagi tot tempestatibus actus heu, genitorem, omnis curae casusque levamen, amitto Anchisen. hic me, pater optime, fessum deseris, heu, tantis nequiquam erepte periclis! nec vates Helenus, cum multa horrenda moneret, hos mihi praedixit luctus, non dira Celaeno.

hic labor extremus, longarum haec meta viarum. hinc me digressum vestris deus appulit oris. Sic pater Aeneas intentis omnibus unus fata renarrabat divum cursusque docebat. conticuit tandem factoque hic fine quievit.

And in the end the port of Drepanum

Took me in, a landing without joy.

For after storms at sea had buffeted me

So often, here, alas, I lost my father Anchises,

Solace in all affliction and mischance;

$\mathrm{O}$ best of fathers, in my weariness-

Though you had been delivered from so many

Perils in vain-alas, here you forsook me.

Never had Helenus the seer, who warned

Of many things to make me quail, foretold

This grief to me-nor had the vile Celaeno.

Here was my final sorrow, here the goal

Of all my seafaring. When after this

I put to sea, god drove me to your shores."

So in his tale before the attentive crowd

Aeneas' single voice recalled the fates

Decreed by heaven, and his wanderings.

He fell silent at last and made an end. ${ }^{65}$

${ }_{5}$ Aen. 3.707-718; trans. adapted from Virgil, The Aeneid, trans. Robert Fitzgerald (New York: Random House, 1981), 90-91. 
Here we have a lament for a father in the most famous poem from Latin antiquity, and it describes his death as occurring after he has quite literally "travelled the Sicilian shore." While in the writing of Mille quingentis it might well have been the bare fact of Willem Obrecht's death on St. Cecilia's day that initiated an associative link with the name of the island, with the words qui Ceciliam peragravit oram the author demonstrates he was interested in more than just clever word play. The significance of this four-word phrase, prepared and heightened by the poem's quotations of Vergil, emerges as an allusion to Anchises's last journey and Aeneas's subsequent lament. The "journey of life" is an overarching metaphor in Vergil's text, one given special emphasis in this scene (longarum haec meta viarum). Later Christian allegorizers are even more explicit in their use of the metaphor, finding philosophical truths on the nature of human life hidden beneath the poetic cover (sub integumento) of Aeneas's journey. ${ }^{66}$ But it is not so much this generalized notion of traveling that lends weight to Obrecht's allusion. It is rather that his phrase, in evoking Vergil's description of the father and son's last journey together, makes Willem into an Anchises-figure. Obrecht, as pius Aeneas, mourns the loss of his Anchises, pater optime, his "solace in all affliction and mischance." ${ }_{7} 7$

In this reading, the motet need not-indeed probably should notbe understood to refer to Willem ever having actually traveled to Sicily. While the text's figurative language does not necessarily exclude the possibility of his having made such a journey, it remains the case that more than half a century of research has shown how thin the evidence for this really is. The point here, however, is that in construing the poem

${ }^{66}$ Cf. the 12 th-century commentary attributed to Bernardus Silvestris: "To the extent that he writes about the nature of human life, Virgil is a philosopher. His procedure is to describe allegorically by means of an integument what the human spirit does and endures while temporarily placed in the human body ... The integument is a type of exposition which wraps the apprehension of truth in a fictional narrative, and thus it is also called an involucrum, a cover" (Commentary on the First Six Books, trans. Schreiber and Maresca, 5).

${ }_{67}$ The apostrophe pater optime is notable as the only instance in which Vergil uses a superlative to describe Anchises. Michael Putnam has commented on the precise echo of this phrase in Dante's Purgatorio (30.49-51), at the point when Vergil ceases to be Dante's guide: Ma Virgilio n'avea lasciati scemi I di se', Virgilio dolcissimo patre, I Virgilio a cui per mia salute die'mi ("But Virgil had left us bereft of himself, Virgil sweetest father, Virgil to whom I gave myself for my salvation." He notes that dolcissimo patre "is the only use in the poem of the superlative of dolce to qualify a person-a climactic, emotional utterance coming at the moment when guide is utterly useless to pilgrim.... The Latinate ring of dolcissimo patre is intentional. It directly recalls the actual moment of Anchises' demise, that is, the point when he, too, is, at least in the body, totally lost to his son." Michael C. J. Putnam, Virgil's Aeneid: Interpretation and Influence (Chapel Hill: Univ. of North Carolina Press, 1995), 302-03. On the use of pater optime in paternal laments by the Ferrarese poets Ludovico Ariosto and Ercole Strozzi see below. 
in this literal fashion we neglect how a work like the Aeneid was read and used in earlier periods, and in turn, miss much of what would have made Mille quingentis meaningful for Obrecht and his contemporaries as a commemorative text.

As with many such allusions, the phrase qui Ceciliam peragravit oram would have depended for its effect on a dual process of recollection and assimilation. In triggering recollection of an extremely famous text (Aeneid) and a constellation of associated ideas (Sicily-Anchises's death -Aeneas's pietas) the allusion defined a classical locus relevant to the subject at hand. The assimilation of these textual elements and their thematic resonances into a contemporary context-a practice which even more than an intimate familiarity with large sections of a classical epic might strike the modern observer as foreign-was a habit engendered by mnemonic, pedagogical, and reading practices common throughout the medieval and Renaissance periods. ${ }^{68}$ As a form of imaginative engagement with classical texts, this type of assimiliation manifested itself in both literary and pictorial works and was of a piece with the broader Christian tendency to naturalize pagan poetry and philosophy.

While the interpretation of Mille quingentis proposed here helps sort out some long-standing problems with understanding the text, and while these initial observations point out cultural practices that would have enabled the author to allude to Vergil's works for such purposes, there arises from all this a new set of difficult and intriguing questions. What, for example, do these Vergilian allusions tell us about Obrecht, other than his acquaintance with some of the best-known poems from antiquity? Was there a poetic tradition that linked Anchises's death and Sicily in comparable fashion of which Obrecht could have been aware, and if so, how? For that matter, what might have prompted him, when faced with commemorating his father's death, to turn to Vergil at all, or to specific passages in Vergil's poetry? Addressing questions of this sort forces us to think about the biography of a $15^{\text {th-century composer }}$ along unfamiliar lines. In offering some provisional answers the remainder of this study takes a closer look at the proximate sources of Mille quingentis in order to delineate better certain aspects of Obrecht's intellectual profile, and to show how these might intersect with the known details of his career.

\section{Paternal Laments and Their Classical Models at the Ferrarese Court}

The first-century Neapolitan poet Statius, whom we have already encountered in Dante's Commedia as an admirer of Vergil, provides an

${ }^{68}$ Carruthers, The Book of Memory, esp. chaps. 1 and 3; Kallendorf, Virgil and the Myth of Venice, chap. 2. 
early example of a writer exploiting the association of Anchises's death and Sicily in the context of a paternal lament. Among the 32 occasional poems that make up the five books of his Silvae there are several laments (epicedia), the longest and most elaborate of which is that for his father, himself an accomplished poet. ${ }^{69}$ Believed to have been written very near the end of Statius's life, and thus about 15 years after his father's death in 79 C.E., the poem runs to 293 lines, which can be divided into roughly four sections: an exordium of sorts in which the poet expresses his grief (ll. 1-115), a long passage devoted to praising his father's accomplishments (1l. 116-252), a description of his death and burial (11. 253-276), and finally, a wish that his father be welcomed gently in the afterworld (11. 277-293). Allusions to the Aeneid, and especially to Aeneas's pietas and Anchises's death, appear throughout the poem. At one point Statius even manages a composite allusion, referring in a single phrase both to Aeneas's inability to embrace his father's shade in Elysium (Aen. 6.700-703), and to their departure from Troy (Aen. 2.707-710). $7^{\circ}$ More striking for our purposes, however, is an allusion early in the poem to the funeral games held in honor of Anchises (Aen. 5). After expressing his desire to build a noble monument over his father, Statius then describes the offerings that should take place there. These should exceed the games for Anchises, as well as those for Opheltes and the Olympian games founded in honor of Pelops:

atque utinam fortuna mihi dare manibus aras,

par templis opus, aeriamque educere molem,

Cyclopum scopulos ultra atque audacia saxa

Pyramidum, et magno tumulum praetexere luco.

illic et Siculi superassem dona sepulchri

et Nemees ludum et Pelopis sollemnia trunci.

Would it were my fortune, to build an altar to your shade, a work that would match temples, to raise high the soaring fabric, higher than Cyclopean rock or the Pyramids' bold masonry,

69 Statius, Silvae, ed. Edward Courtney (Oxford: Clarendon Press, 1990); quotations from the Latin text follow this edition. Silves, ed. Henri Frère, trans. H. J. Izaac, 2 vols. (Paris: Société d'édition "Les Belles lettres," 1961) provides extensive notes on Statius's references to earlier texts. As this lament reveals, Statius benefited from his father's tutelage in poetry; on his father's career as a poet and its significance in Statius's epicedion see Alex Hardie, Statius and the Silvae: Poets, Patrons and Epideixis in the Graeco-Roman World (Liverpool: Francis Cairns, 1983), 2-14.

$7^{\circ}$ Silvae 5.iii.266-268 felix ille patrem vacuis circumdedit ulnis I vellet et Elysia quamvis in sede locatum I abripere et Danaas iterum portare per umbras ("Happy was he who grasped his father with empty arms; he would have snatched him away, though set in Elysium, and carried him once more through Danaan darkness"); trans. after Statius, ed. and trans. John Henry Mozley, 2 vols. (Cambridge: Harvard Univ. Press, 1967), 1: 327 . On Statius's approach to the conventions associated with consolationes and epicedia, see Stephen Thomas Newmyer, The Silvae of Statius: Structure and Theme (Leiden: Brill, 1979), 19-24, 64-74. 
and plant a mighty grove about your tomb.

There had I surpassed the tribute of the Sicilian sepulchre, and Nemea's games and the rites of maimed Pelops..$^{11}$

Statius's world being in many ways still so consonant with Vergil's, the allusion to the funeral games for Anchises does not stand in such high relief as it would in a Christian poetic context. It nevertheless provides a literary-historical model against which Statius's lament is to be read, and in its identification of Aeneas's pietas with the poet's own devotion to his father the allusion functions in a manner similar to Obrecht's qui Ceciliam peragravit oram, something which the obvious discrepancy in their respective literary skills in no way diminishes. Moreover, given

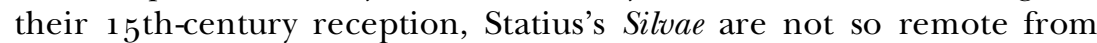
Obrecht's world as they might seem.

Dante, writing in the early $14^{\text {th }}$ century, would have identified Statius only as a writer of epics, as author of the Thebaid and the unfinished Achilleid, the reason being that the Silvae were virtually unknown throughout the Middle Ages. They were among the classical texts Poggio Bracciolini discovered at Constance and St. Gall in the early $15^{\text {th }}$ 436 century, copies of which he sent back to Italy. The earliest complete manuscript of the Silvae, from which most all other manuscripts of the work derive, dates from about $143^{0.7^{2}}$ The appearance of the editio princeps, published in Venice by Vindelinus de Spira in 1472 (just two years after the first Venetian edition of Vergil, from the same printer), sparked wider interest in the poems, and other editions soon followed: in 1473 (in Parma), in 1475 (in Rome, including a full Latin commentary by Domitius Calderini), in 1494 (again in Venice), and on into the 16th century.73 It is indicative of the importance Italian humanists early

${ }_{71}$ Silvae 5.iii.47-52; trans. after Statius, ed. Mozley, 307. The earliest surviving complete manuscript of the Silvae, copied ca. 1430 and containing many problematic readings, gives lucum ("groves") at 1.52 . On the reasons for emending this to ludum, a suggestion first made in the 18 th century though accepted by comparatively few recent editors, see Lennart Håkanson, Statius'Silvae: Critical and Exegetical Remarks with Some Notes on the Thebaid (Lund: CWK Gleerup, 1969), 141, with further references given there. Statius goes on to specify (11. 53-63) that these "games" would be not athletic, but literary, with the poet singing his father's praise in hopes of equaling the "stern pietas" of Vergil (tenderet et torvo pietas aequare Maroni).

$7^{2}$ This manuscript, the so-called Codex Matritensis, can not be identified with the one Poggio sent to Italy, which Poliziano described in the late 1470 as a libro vetustissimo. At least one intermediate copy separated the Matritensis from the probably much older manuscript Poggio found; see the preface to Statius, Silvae, ed. Antonio Traglia (Torino: Paravia, 1978), v-xxxiv, for a discussion of the connections among these early sources. Some of the poems from the Silvae appear to have been known in the Carolingian era, judging from a few short imitations and paraphrases that survive from that time; Silvae, ed. Courtney, vi-viii.

73 The 1475 Roman edition with commentary, published by Sweynheim and Pennartz, was reprinted at least four more times by 1498; Paul M. Clogan, "The Latin Com- 
attached to the Silvae that in $1480-81$, less than a decade after the first printing, Angelo Poliziano (1454-94) chose to devote his first course of lectures at the Florentine Studio to the work. A redaction of his extensive notes on the poems survives in a manuscript of more than 140 folios (most in his own hand).74 His commentary is selective, not systematic, with a majority of its entries reserved for explications of names and places mentioned by Statius and their significance. Drawing on his knowledge of classical authors (both Greek and Latin), the more extended comments often trace the literary sources of Statius's references, especially it seems where either the source text was less well known or Statius's use of it somehow difficult or obscure. Given this tendency, his comment on Statius's allusion to the funeral games in Sicily is revealing. The brevity of his annotation ("Siculi. Anchisae") suggests this was something he considered self-evident; so obvious was the association of the "Sicilian sepulchre" with Anchises that it required no further explanation. 75

Poets quickly added the Silvae to their common reservoir of classical source texts. The seemingly impromptu nature of some of Statius's occasional poems, with their illusion of spontaneity, appealed to certain humanist writers (including Poliziano) and offered a new model for their own works of this sort. $7^{6}$ The Statian epicedion, meanwhile, provided humanists with a rich body of themes and figures on which to draw for their epitaphs, eulogies, and other types of commemorative poetry. Of particular relevance here are two paternal laments written at the very beginning of the 16 th century by poets at the Ferrarese court,

mentaries to Statius: a Bibliographic Project," in Acta Conventus Neo-Latini Lovaniensis, eds. Jozef IJsewijn and Eckhard Kessler (Leuven: Leuven Univ. Press, 1973), 149-57. For chronologies of Latin and Italian editions of Vergil published in Venice and the Veneto through the late 16th century, see Kallendorf, Virgil and the Myth of Venice, 213-21.

74 Commento inedito alle Selve di Stazio, ed. Lucia Cesarini Martinelli (Florence: Sansoni, 1978$)$.

75 Ibid., 740.

${ }^{6}$ Poliziano's own Silvae are astonishing mosaics of classical references so densely interwoven as to strain current notions of intertextuality almost to breaking point. They were presented as opening addresses to four of his academic courses in Florence (1482-86), focusing on the works of Vergil, Homer and Hesiod. Exceptionally for Poliziano, all but the last were published very soon after their public recitations. Angelo Poliziano, Silvae, ed. Francesco Bausi (Florence: Olschki, 1996). The use of the word silva (literally, "forest") to describe a type of impromptu writing done in the heat of the moment was already well enough established by the time of Quintilian for him to criticize the method (Institutio oratoria, 1o.iii.17). That both Statius's and Poliziano's Silvae are in fact carefully wrought works reflects the inherent conceit of the title. In the context of antique rhetorical theory, the term was used metaphorically in discussions of mnemonics to describe the untrained memory, which was considered a "forest" of disordered material in need of structuring; see Carruthers, The Book of Memory, 204. In this regard the title of Statius's collection is telling: his allusions and quotations, in placing portions of familiar literary works within "memorable" new contexts, are in accordance with one of the basic precepts of classical mnemonics. 
the one Italian court with which Obrecht is known to have been associated, first as a distinguished visitor in $1487-88$, and then again at the end of his life as Ercole d'Este's maestro di cappella (1504-05).

The first of these is the young Ariosto's lament on the death of his father, who (like Ariosto himself from 1497 to 15 oo) served at the Este court.77 Almost all of Ariosto's Latin poetry was written during the years $1494^{-1} 5^{\circ}$, and this lament likely dates from shortly after his father's death in February ${ }^{1} 5^{00.7^{8}}$ While much shorter than Statius's epicedion for his father (a mere 24 lines) and in a different meter, Ariosto's poem relies heavily on the earlier text for its central motif of mourning (the son offering his tears as a gift to the father) 79 and for much of its imagery and vocabulary. ${ }^{80}$ The allusions in Statius's poem to Anchises's death and Aeneas's pietas echo through Ariosto's text as well, though mostly these constitute Vergil as heard through a Statian filter. In a passage beginning in line 5 , however, Ariosto's evocation of the world of the Aeneid—and Aeneas's lament in particular-becomes clear:

has dono, pater optime, sincerae monimentum illius, illius quam noras pietatem, imperiis tuis sanctis a tenera huc usque puertia, cum semper fuerim obsequens. (11. $5^{-9}$ )

As throughout the poem, Ariosto is here addressing his dead father. $\mathrm{He}$ offers his tears as a sign of his pietas, which has manifested itself in his having always complied with his father's "sacred wishes" (imperiis tuis sanctis; cf. Aeneas, who upon returning to his father's tomb, addresses

77 De Nicolao Areosto; Ludovico Ariosto, Opere minori, ed. and trans. Cesare Segre (Milan: Riccardo Ricciardi, 1954), 28-29. On references in Ariosto's Latin lyrics to classical poetry see Elvira Pace, "Le liriche latine dell'Ariosto," Giornale italiano di filologia 14 (1961): 104-28. A valuable study of Ariosto's early poetry in relation to the literary environment at Ferrara is Emilio Bigi, "Vita e letteratura nella poesia giovanile dell'Ariosto," Giornale storico della letteratura italiana 145 (1968): 1-37; Bigi also discusses the possible influence of Michele Marullo's lament for his brother (cited in $n_{5} 1$ above) on Ariosto's for his father.

${ }^{8}$ Opere di Ludovico Ariosto, vol. 3, ed. Mario Santoro (Torino: Unione TipograficoEditrice Torinese, 1989), 18-27; Michele Catalano, Vita di Ludovico Ariosto, 2 vols. (Geneva: Olschki, 1931).

79 Ll. 1-3 Has vivens lacrimas, sed qui odio miser I tristem vitam habeo, dono, pater, tibi, I vitae sollicitis functe laboribus; cf. Statius, Silvae 5.iii.45-46 sume-gemitus et vulnera nati I et lacrimas, rari quas umquam habuere parentes.

8o Ariosto asks that his father receive this last gift (i.e., his tears) whether he is now dwelling in the pure heavens (11. 9-10 seu liquidi aetheris I cultor), or in the barren groves of Elysium among the shades of friends who died before him (11. 13-16 seu lucos steriles et nemus Elysi I incedis vacuum, perque silentia I iucundos comites quos prior abstulit I hora agnoscis). Both the sentiment and the seu/seu construction appear in Statius's poem (Silv. 5.iii.19-25). Ariosto also follows Statius in comparing the gift of his lament to the offering of rare spices and blossoms of Arabia at his tomb (Ariosto, 11. 17-2 2; Statius, 11. 4144). Curiously, all three of Ariosto's references to Statius's text come from 11. 19-46. 
him with the words salve, sancte parens, iterum [Aen. $5.8 \mathrm{o}])$. This lifelong devotion to a father is enough, given the rest of the poem, to hint at a poetic identification with pius Aeneas, but it is the apostrophe pater optime that sounds the strongest Vergilian note. For a careful reader of Vergil's epic-which the future author of Orlando furioso surely wasAeneas's use of this phrase (Aen. 3.710-711: hic me, pater optime, fessum I deseris, heu, tantis nequiquam erepte periclis) would have been memorable on two counts. First, and most obviously, it marks the emotional climax of his lament, the most forceful expression of a son's sense of loss and abandonment. Second, and no less significant, it is the only place in the work where Vergil assigns a superlative to Anchises. ${ }^{81}$

The second poem is by Ercole Strozzi (ca. 1470-15o8), one of Ariosto's literary companions at the Ferrarese court. Strozzi is perhaps best known to music historians as author of the poem Virgo salutiferi, which Josquin set as a five-voice motet, probably during his time in Ferrara as maestro di cappella $(15 \mathrm{O} 3-04) .{ }^{82}$ An accomplished poet in both Latin and Italian verse, Strozzi was also the son of a poet, the more renowned Tito Vespasiano Strozzi $\left(14^{2} 4^{-1} 5^{05}\right)$, whose distinguished career at the Ferrarese court, as poet and later civil administrator, extended back to the mid $15^{\text {th }}$ century. ${ }^{8}$ Ercole's epicedion for his father, written sometime between $15^{05}$ and his own death in $15^{08}$,

${ }^{81}$ The end of Aen. 3 is the only classical example known to me in which the phrase pater optime is used in a lament, and at all events this would have been the best known instance of it from antiquity. The apostrophe appears elsewhere in the Aeneid (1.555 sin absumpta salus, et te, pater optime Teucrum); here the pater is Aeneas, and though not a lament, it is telling that the speaker in this passage is uncertain of Aeneas's fate and fears him dead. Vergil signals Aeneas's new status following Anchises's death by referring to him often as pater Aeneas (beginning at Aen. 3.716, immediately after his lament for Anchises). There are two other occurrences of pater optime in works by other important classical poets, neither of which appears in the context of a lament: Ovid, Metamorphoses 7.627 Dum numerum miror, 'totidem, pater optime' dixi, (Aeacus, king of the Myrmidons, addressing his father, Jupiter), and Horace, Satires 2.i. 12 cupidum, pater optime, vires (where the poet is addressing Trebatius, a celebrated lawyer, seeking advice on whether he should desist from writing satires). On Dante's recognition of the phrase's distinctly Vergilian associations and its significance as an extreme expression of loss, see $n 67$ above.

$8_{2}$ On Strozzi's authorship of the text see The Medici Codex of ${ }_{5}$ I 8 , ed. Edward E. Lowinsky, Monuments of Renaissance Music, 3 (Chicago: Univ. of Chicago Press, 1968), 199-200; Lewis Lockwood, Music in RenaissanceFerrara, I4OO-I5O5 (Cambridge: Harvard Univ. Press, 1984), 207, 260.

${ }_{3}$ The elder Strozzi was an accomplished poet already in his teens. His first collection of elegies, dedicated to Leonello d'Este, appeared in 1443; his four epitaphs for Niccolò III d'Este (discovered only in the 196os) also presumably date from the early 1440 ; Wolfgang Speyer, "Vier unbekannte Grabgedichte des Tito Vespasiano Strozzi," Rinascimento, seconda serie 8 (1968): 323-26. Around 146o he began his epic Borsiade (left unfinished) in honor of Borso d'Este. He continued to serve at the Ferrarese court under Ercole, and in 1497 was named judge of the 12 Savi; Vittorio Rossi, Il Quattrocento (Milan: Francesco Vallardi, 1933; repr. 1973), 225 -26, 234; on stylistic features of Strozzi's shorter poems see Leicester Bradner, "The Neo-Latin Epigram in Italy in the Fifteenth Century," Medievalia et Humanistica 8 (1954): 62-70. See also Lockwood, Music in Renaissance Ferrara, 92. 
follows the structure of Statius's Silvae 5 .iii to a much greater degree than does Ariosto's poem. ${ }^{8}{ }_{4}$ Perhaps a perceived parallel with Statius (whose father was also a poet) prompted Ercole to adhere so closely to his model. Some $5^{o}$ lines longer than Statius's lament, Ercole's poem seems also an attempt to outdo its model in other ways. Whereas Statius, for all his allusions to earlier poetry, mentions by name only three poets (Homer, Vergil, and Sappho), Ercole is even more explicitly "literary," citing Vergil, Cicero, Plautus, Tibullus and others. The structural and thematic similarities between the two (an exordium of grief, a long recitation of the father's accomplishments) extend to their shared reliance on Vergil's works as important source texts. ${ }^{85}$ And like Ariosto, Ercole employs the apostrophe pater optime, though here in a passage even more heavily dependent on Vergil. Praising his father's love (amor), devotion (pietas), and inner courage (conscia virtus), ${ }^{86}$ the poet asks "What thanks, what then shall I give back to you, best of fathers (pater optime)?" 7 The echoes of Aeneas's lament continue as Ercole describes his father as having been both guide and example for him (ll. 289-290: astraque adibam I Te monstrante viam). And in conveying his sense of loss he evokes a Vergilian journey at sea: Without his father he 440 is thrown off a straight course, just as a ship deprived of its guiding helmsman (spoliata magistro) is driven here then there by stormy winds. ${ }^{88}$ Ercole's allusions to the Aeneid take a form distinct in certain ways from both Statius's and Ariosto's, but the close cross-hatching here of Vergilian phrases and images points unmistakably to his source text.

${ }_{4}$ Titi Vespasiani Strozae Poetae Illustris Epicedium per Herculem Filium, first publ. in Strozii poetae pater et filius (Venice: Aldo Manuzio, ${ }_{15}^{1} 3$ ), fols. $39^{\mathrm{r}}-44^{\mathrm{v}}$; all references are to this edition. I am indebted to Jane Alden for making a copy of this edition available to me.

$8_{5}$ An explicit instance in Ercole's poem is his paraphrase of the opening of Vergil's First Eclogue (Tityre, tu patulae recubans sub tegmine fagi) as Tam bene, uti valeat patulae sub tegmine fagi I Tityre (fol. 41v, ll. 168-169). Use of this verse as a more general marker of pastoral poetry goes back to Vergil himself, who in a self-conscious reference to his earlier Eclogues gives a near exact quotation of it at the end of his Georgics (4.562-565): illo Vergilium me tempore dulcis alebat I Parthenope, studiis florentem ignobilis oti, I carmina qui lusi pastorum audaxque iuventa, I Tityre, tu patulae cecini sub tegmine fagi.

86 The phrase conscia virtus appears twice in the Aeneid: 12.668 et furiis agitatus amor et conscia virtus, and 5.455 Tum pudor incendit vires et conscia virtus.

${ }_{7}$ Quas tibi, quas igitur referam pater optime grates? (fol. $43 \mathrm{v}, 1.285$ ).

88 Sine te iam limite recto I Excutior, veluti docto spoliata magistro I Huc illuc agitur nimboso turbine pinus. (fol. 43v, 11. 290-292). The phrase spoliata magistro occurs twice in the Aeneid, both times in connection with a ship's helmsman; see Aen. 5.224 (concerning the shipraces at the funeral games for Anchises) and Aen. 6.353 spoliata armis, excussa magistro, where in the underworld the shade of Palinurus, Aeneas's helmsman, describes how he was thrown overboard and lost. To my knowledge the phrase does not appear elsewhere in classical Latin poetry. For the final phrase of this passage, agitur nimboso turbine pinus, cf. Ovid, Metamorphoses $11.55^{1}$ Frangitur incursu nimbosi turbinis arbor. 
Presumably further investigation would turn up other examples of paternal laments by Italian humanists that allude to the Aeneid (perhaps even to Aeneas's lament), either directly or through an intermediary text such as Statius's epicedion. I have described these two Ferrarese poems at some length in part to show that this particular practice of using Vergil's poetry in laments, one akin to that found in Mille quingentis, existed at the Italian court with which Obrecht is known to have been associated at two points in his career. Having said this, it should immediately be pointed out that Obrecht could have known neither Ariosto's poem nor Strozzi's when he composed his motet. If he was aware of these laments at all this could really only have happened after his return to the Este court as maestro di cappella in September 1504, by which time Mille quingentis had existed for perhaps as much as 15 years. The first printings of the two Ferrarese poems occurred only years after Obrecht's death, and there is little reason to believe that either work circulated widely in manuscript. ${ }^{89}$ Their significance for Obrecht's text, therefore, is not as models he could have attempted directly to emulate. Rather, it is what these poems tell us about both current and earlier literary tendencies at the Ferrarese court. In employing these kinds of allusions the two young humanists were surely not setting a precedent, but rather following an already established practice they had learned from their teachers in Ferrara. ${ }^{\circ}$ In other words, the treatment of classical texts in their respective paternal laments alerts us to the types of literary practices Obrecht might have encountered already during his first visit to Ercole d'Este's court (Dec. 1487-May 1488).

Doubtless magister Jacobus was familiar to some extent with Vergil's poetry before traveling to Ferrara; probably already as a schoolboy he would have known at least bits of the Aeneid by heart. His university studies could have provided an opportunity to expand on his knowledge of classical literature, though this would very much have depended on where those studies occurred, unfortunately something we still do not know. There are also the various churches at which Obrecht worked, perhaps the most significant in this respect being the collegiate church of St. Donatian in Bruges, where in October 1485 he was appointed succentor. The city's long-standing commercial and diplomatic ties to a

${ }^{89}$ Both poems were published posthumously: Ariosto's in 1553 , Strozzi's in $15^{13}$. If for some reason Obrecht composed Mille quingentis not in the period immediately following his father's death but closer in time to the copying of its earliest surviving source (ca. $15^{\mathrm{OO}-03}$ ), then there is a slight possibility that Ariosto's lament could have been written first. Even so, the chances are remote that Obrecht could have encountered the poem before 1504 .

9o Judging from his lament, perhaps the most important of Ercole's teachers was his father, Tito Vespasiano; for Ariosto, the tutelage of Gregorio da Spoleto was of special importance to his literary studies; see Opere di Ludovico Ariosto, vol. 3, ed. Santoro, 10-1 2. 
number of Italian centers engendered the types of cultural exchange that played such an important role in disseminating humanistic learning in the North. As early as the $14^{\text {th }}$ century the chapter library of St. Donatian's possessed works by Terence, Martial and other classical authors, and Strohm relates that by the 1480 os the schoolmaster there had instituted annual recitations in Latin to be performed by the schoolboys on certain feast days. In 1484, the year before Obrecht arrived, they recited the first book of the Aeneid, and in 1486 a "comedie" by Lucian.91 Obrecht's immediate predecessor, Aliamus de Groote, was a respected poet as well as a composer and he presumably had a hand in promoting such activities at St. Donatian's. Whether Obrecht took a comparable interest in these recitations is unclear. His musical duties as succentor were considerable, and there is reason to believe he had difficulty staying on top of all that was required of him.92 At the same time, there is the intriguing Latin poem that appears in the tenor of his Missa Salve diva parens, a work copied in Rome ca. 1487/88 and almost certainly composed during his first two years at Bruges.93 This otherwise unknown four-line poem, addressed to the Virgin but in language containing echoes of Vergil and Ovid, uses a meter not found in classical 442 Latin poetry.94 Strohm, however, has discovered the same meter in a Marian hymn attributed to the 9th-century musician Hucbald of SaintAmand. In suggesting that the poem in Obrecht's Mass might have been intended as newly-composed verses for this Carolingian hymn, he speculates that "the humanist flavour of the stanza could well have been within the reach of a Bruges poet such as Aliamus de Groote."95 Given the text of Mille quingentis perhaps we should even allow for the possibility that Obrecht himself wrote these lines.

By the time the authorities at St. Donatian's granted Obrecht a leave of six months in order to travel to Ferrara, in October 1487, a number of his compositions must have been circulating in Italy. As is well known, his leave from St. Donatian's was the result of a request from Ercole d'Este to have the composer come to his court "and stay there for sev-

${ }^{11}$ Strohm, Music in Late Medieval Bruges, 19, 36.

$9^{2}$ The chapter dismissed Obrecht in Jan. 1491, though he returned to serve as succentor again from 31 Dec. 1498 to 3 Sept. 15 oo. On Obrecht's time in Bruges see Strohm, Music in Late Medieval Bruges, 38-41; Wegman, Born for the Muses, $138-39,15^{6-}$ 60 .

93 Strohm, Music in Late Medieval Bruges, 148; Wegman, Born for the Muses, $175^{-89}$. The poem appears in two of the six sources that preserve the Mass in complete or nearcomplete form: Vienna, Nationalbibliothek Mus. 15495 and Leipzig Universitätsbibliothek 1494 .

94 Martin Staehelin, "Obrechtiana," Tijdschrift van de vereniging voor nederlandse muziekgeschiedenis 25 (1975): 1-37, at 20-23; Wegman, Born for the Muses, 178n28.

95 Strohm, Music in Late Medieval Bruges, 148. 
eral months." ${ }^{6}$ Thus Obrecht was not simply a casual visitor, but a distinguished guest of the duke, who apparently valued him primarily as a composer and immediately set about trying to secure benefices for him. Little wonder, then, that Obrecht, who was supposed to be back at his post in Bruges no later than mid April 1488, departed Italy only in May and did not actually return to Bruges before mid August. This willingness to disobey the authorities at St. Donatian's suggests the measure of his desire to find employment at one of the Italian courts. Despite the efforts of Ercole and his agents, however, nothing seems to have come Jacob's way and he returned to the North empty-handed. With his return to Bruges, personal loss soon added to the composer's difficulties: Willem Obrecht's death occurred less than four months after the end of Jacob's travels.

It is worth bearing in mind both the special circumstances of Obrecht's first extended stay in Ferrara and the proximity of that visit to his father's death. As a prized guest at Ercole's court, one moreover who had no regular duties to attend to, he would have had both the time and the opportunity to meet with others in the duke's retinue. Whatever humanistic literature he might have come to know during those months, at court but perhaps also through contact with the Ferrarese Studio, would have offered a rich and, to him, probably new engagement with classical writings. He would also have been in a better position to discover classical works still less well known outside Italy, such as Statius's Silvae, possibly in one of the several editions that had recently been printed. 97 Perhaps equally important as these discoveries, there would have been the potential for new types of access to classical texts. Here we might note that about halfway through his six-month

${ }^{96}$ Ercole's request was presented to the chapter of St. Donatian's by his singer Cornelio di Lorenzo and the famous tenorist Johannes Cordier; Lockwood, Music in Renaissance Ferrara, 163-64. The chapter acts of St. Donatian's record that Cordier "reported that the same duke [Ercole] takes much delight in the art of music, favours the musical composition of the said magister Jacob above other compositions, and has long wished to see him"; Wegman, Born for the Muses, 141. From three years earlier (1484) dates the first direct documentation of Ercole's interest in Obrecht, and again Cornelio di Lorenzo is involved: Ercole writes acknowledging receipt of a copy of one of Obrecht's Masses that Cornelio had sent to him from Florence; Lockwood, Music in Renaissance Ferrara, 162-63. The remainder of this paragraph follows the much more detailed account of Obrecht's travels given in Wegman, Born for the Muses, $13^{8-47}$.

97 There were also the manuscript copies of classical works that continued to be produced in Ferrara. In 1474 a vellum manuscript with illuminated initials containing all three of Vergil's major works was copied there (now Princeton Univ., MS $3_{6} 6$ ). This was apparently not simply a display book for its early 16 th-century Venetian owner, who highlighted portions of the text in numerous places. As Kallendorf notes, this owner "mined the book for sententiae, memorable lines whose moral contents [made] them useful guides amid the confusions and setbacks of daily life"; Kallendorf, Virgil and the Myth of Venice, 31-32. 
stay in Italy, in March 1488 , the most important $15^{\text {th-century commen- }}$ tary on the Aeneid was published in Florence. Its author, Cristoforo Landino, had lectured on Vergil at the Florentine Studio as early as the 1460 s and had already devoted the last two books of his Disputationes Camaldulenses (first published in 1480) to a moral allegorization of Books 1 through 6 of the Aeneid. His line by line commentary of 1488 quickly took its place in many printed editions of Vergil's poetry next to the venerable late-antique commentaries of Servius and Donatus. $9^{8}$ In his earlier Disputationes, Landino aimed to present a novel interpretation of the hidden moral content of the Aeneid, as the following passage from his introductory comments makes clear:

Neither grammarian nor rhetorician knows this, but it must be brought to light from the deepest secrets of philosophy, for you wish to know what Virgil meant in his mysteries concerning the wanderings of Aeneas and the departure of that man to Italy.99

It is interesting to note as well that Landino, unlike most other commentators on the Aeneid, focused on Book 3 of the poem and its moral ramifications. It is of course at the end of this book that Aeneas's lament for Anchises appears. ${ }^{100}$

For someone not well-versed in humanist approaches to and uses of classical literature, however favorably disposed he might be toward such endeavors, this wealth of texts and interpretations would have been too much to assimilate in a short period of several months. More than newly polished literary skills, what Obrecht could have taken back with him to the North was a fuller awareness of these literary possibilities and perhaps an increased interest in classical poetry generally. Considered in this light, the hybrid nature of Mille quingentis, with its mixture of different poetic conventions, begins to make more sense. Willem

$9^{8}$ Cristoforo Landino, Disputationes Camaldulenses, ed. Peter Lohe (Florence: Sansoni, 1980). Landino taught rhetoric and poetry at the Studium Florentinum from $145^{8}$ until his death in 1498. In the Disputationes he describes the underlying philosophical content of poetry as a "civic theology." His approach to the Aeneid exemplifies a humanistic inclination to regard the poem as a guide to moral philosophy; see Craig Kallendorf, "Cristoforo Landino's Aeneid and the Humanist Critical Tradition," Renaissance Ouarterly 26 (1983): 519-46. Landino's commentary was included in 19 of the 35 printed editions of Vergil that appeared between 1488 and 15 oo; Craig Kallendorf, In Praise of Aeneas: Virgil and Epideictic Rhetoric in the Early Italian Renaissance (Hanover, N.H.: Univ. Press of New England, 1989), 129.

99 Kallendorf, "Cristoforo Landino's Aeneid," $5^{2} 3^{-24}$; Latin text in Landino, Disputationes, ed. Lohe, $117-18$.

100 Kallendorf, "Cristoforo Landino's Aeneid," 538-41. Landino's concern in this work is with impediments to moral development (the commentary to Aen. 3 deals specifically with avarice), an indication of the emphasis in humanist circles on interpreting Aeneas's journey from the standpoint of moral philosophy. From Obrecht's text alone it is not possible to say whether he was aware of Landino's commentary. 
Obrecht's death, occurring so soon after the composer's own "wanderings" in Italy, might have presented him with the first occasion since his return serious enough to merit this type of literary effort. Starting from a textual tradition familiar to him, that of the medieval epitaph, he would then have grafted on to this framework classical phrases and allusions relevant to the subject in emulation of what he knew of humanistic poetic practices. If it is the poem's explicit reference to Jacob that most strongly supports his authorship, this conflation of textual types seems to offer the clearest reflection of his background and experiences.

\section{Obrecht and Tinctoris's Complexus effectuum musices}

The precise nature of Obrecht's experiences with humanists at Ferrara can only be guessed at, of course. We can however gain some sense of the impact his time there could have had by turning to the theorist/composer Johannes Tinctoris (ca. $1435^{-1} 5^{11}$ ), in whose career and writings we find evidence of the ways in which Italian humanism affected another "homespun northerner." ${ }^{101}$ The characterization is Ronald Woodley's, who in a valuable series of studies published over the last 20 years has demonstrated Tinctoris's ambitious and thoroughgoing attempt to acclimate himself to the world of Italian humanistic discourse, beginning even in his first few years of service at the Aragonese court in Naples. ${ }^{102}$ Trained in the North and possessor of a still awkward and overblown Latin style in the early 1460 , Tinctoris was

${ }^{101}$ Ronald Woodley, "Renaissance Music Theory as Literature: On Reading the Proportionale Musices of Iohannes Tinctoris," Renaissance Studies 1 (1987): 211 . That the influence of humanistic learning can be traced more clearly in the case of Tinctoris than in those of many other northern musicians who worked and traveled in 15th-century Italy only underscores the obvious point that the core interests of the studia humanitatis all concerned language, not music. It follows that the language used in a theorist's writings can be assessed with a type of precision less readily available to the student of musical style. In recognizing this distinction I do not mean to suggest that humanistic concerns would have had little influence on how northern musicians composed polyphony, only that the evidence of such influence will necessarily differ in kind from that discussed here. In his study of contrapuntal allusions Christopher Reynolds presents a compelling argument for northern composers' "remarkable ability to adapt their sophisticated techniques to rhetorical modes of expression advocated by Italian humanists"; see his Papal Patronage and the Music of St. Peter's, $1380-1513$ (Berkeley: Univ. of California Press, 1995), 249-97.

${ }_{102}$ Ronald Woodley, "Iohannes Tinctoris: A Review of the Documentary Biographical Evidence," Iournal of the American Musicological Society 34 (1981): 21 7-48; idem, "The Proportionale musices of Iohannes Tinctoris: A Critical Edition, Translation and Study," 2 vols. (Ph.D. diss., Oxford Univ., 1982); idem, "The Printing and Scope of Tinctoris's Fragmentary Treatise De inventione et vsv mvsice," Earlv Music History 5 (1985): 239-68; idem, "Renaissance Music Theory as Literature"; idem, "Tinctoris's Italian Translation of the Golden Fleece Statutes: a Text and a (Possible) Context," Early Music History 8 (1988): 173-244; idem, "Tinctoris, Johannes," in New Grove Dictionary of Music and Musicians, 2nd ed. (New York: Grove's Dictionaries, 2000) [hereafter NG II ]. 
capable by ca. 1473 of a full-scale imitatio of Cicero in the prologue to his Proportionale musices, as Woodley has shown. He wrote the Proportionale only a year or so after joining the household of Ferrante of Aragon, suggesting intensive study of classical auctores after his arrival in Naples (if not before), reinforced by a predisposition toward literary expression. ${ }^{103}$

Even given his years in residence at the Aragonese court and his apparent knowledge of the classicizing literary culture that flourished there, Tinctoris's writings suggest that his intellectual and spiritual moorings continued in large measure to be the traditions in which he had been brought up. We see this not only in the theological and devotional facets of Tinctoris's last treatise, De inventione et usu musice (written between 1480 and 1487 ), but also in his earlier work on the spiritual and emotional effects of music, Complexus effectuum musices (ca. 1472-75). ${ }^{104}$ Woodley has found evidence that Tinctoris revised the Complexus around 1481-83 with the intention of incorporating it into the much larger De inventione, an indication perhaps that the theorist himself recognized a similar orientation in the two works.

Long regarded as something of a curiosity piece among his more practically-oriented treatises of the 1470 s, the Complexus has received a good deal of attention in recent years from scholars interested in late medieval musical aesthetics. ${ }^{105}$ Tinctoris provides a list of 20 effects of music, a number of them broadly religious in nature (music adorns the praises of God, makes the Church Militant like the Church Triumphant, stirs the soul to devotion, etc.). ${ }^{106}$ Others suggest a recogni-

103 Woodley, "Renaissance Music Theory as Literature," 212-19; on evidence of the theorist's linguistic skills and literary interests see idem, "Tinctoris's Italian Translation," $177-78$. On Tinctoris's engagement with other aspects of classical rhetoric see Sean Gallagher, "Models of Varietas: Studies in Style and Attribution in the Motets of Johannes Regis and his Contemporaries" (Ph.D. diss., Harvard Univ., 1998), 39-78.

${ }_{104}$ Woodley ("Tinctoris's Italian Translation," 202) sees in De inventione both a reflection of the pietism characteristic of northern humanism and an expression of the theorist's "own feelings of cultural and philosophical ambivalence towards the new 'Renaissance' spirit abroad in the Italy of the $147 \mathrm{os}$ and $148 \mathrm{os";}$ see also the comments in idem, "The Printing and Scope," 257.

${ }^{105}$ See in particular Reinhard Strohm's introduction in On the Dignity $\mathcal{E}$ the Effects of Music: Egidius Carlerius, Johannes Tinctoris. Two Fifteenth-Century Treatises, ed. and trans. Reinhard Strohm and J. Donald Cullington (London: Institute of Advanced Musical Studies, King's College, 1 996), 6-15; Christopher Page, "Reading and Reminiscence: Tinctoris on the Beauty of Music," Journal of the American Musicological Society 49 (1996): 1-31; Rob C. Wegman, "Sense and Sensibility in Late-Medieval Music: Thoughts on Aesthetics and Authenticity," Early Music 23 (1995): 299-312. See also Luisa Zanoncelli, Sulla estetica di Johannes Tinctoris con edizione critica, traduzione e commentario del Complexus effectuum musices (Bologna: Arnaldo Forni, 1979); Johannis Tinctoris Opera Theoretica, ed. Albert Seay, Corpus Scriptorum de Musica 22/II (American Institute of Musicology, 1975), 158-77.

${ }_{106}$ Dei laudes decorare, Ecclesiam militantem triumphanti assimilare, Animus ad pietatem excitare. A heavily revised and abridged version of the Complexus in Cambrai, Bibliothèque Municipale, MS $A_{4} 16$, fols. 1 or-11v, lists 27 effects in all (though the treatise's 
tion of the place of music among the joys and pains of everyday life (music heals the sick, lightens the burden of work, drives away sadness, attracts love, and makes people joyful). The distinguishing feature of the work is that each of these effects is "illustrated" through quotations from other texts. As Christopher Page has observed, "no other list of music's properties-and there are many of them in the pages of the medieval theorists-is adorned with so many citations." ${ }^{107}$ It is noteworthy that none of Tinctoris's citations come from texts on music. Boethius, for example, is conspicuously absent. Of its approximately 6o carefully signaled quotations, more than half are drawn from classical texts (especially Vergil and other Latin poets, Quintilian, and Aristotle). The remainder come from the Bible and from works by patristic (Augustine) or medieval authors (Aquinas, Bernard of Clairvaux, Isidore, Avicenna). Thus Tinctoris's contribution to the treatise, apart from that of compiler, comprises a short prologue and the brief (though often interesting) comments that accompany many of the quotations. Recent studies by Page, Strohm, and Klaus-Jürgen Sachs have demonstrated the value of attending very closely not only to the texts Tinctoris chose to cite, but also to the intermediary sources through which he knew some of those texts. ${ }^{108}$

The Complexus is often mentioned in connection with Obrecht as evidence of his having achieved renown as a composer while still very young. The basis for this claim is tenuous at best. The treatise survives (in different versions and in varying degrees of completeness) in three sources: a possible authorial holograph copied at Naples in $1477-78$, and two other manuscripts copied in the North during the late $15^{\text {th }}$ and early 16 th centuries. ${ }^{109}$ It is in one of these northern sources,

Prologue in this ms. still specifies only twenty) and presents them in a different order from that given in its other two sources (see n 109 below); Woodley, "The Printing and Scope," 251-53, with an edition of this version of the Complexus on 263-66.

107 Page, "Reading and Reminiscence," 14.

${ }_{108}$ Page, "Reading and Reminiscence"; Klaus-Jürgen Sachs, "Zur Funktion der Berufungen auf das achte Buch von Aristoteles' 'Politik' in Musiktraktaten des 15 . Jahrhunderts," in Musik und die Geschichte der Philosophie und Naturwissenschaften im Mittelalter, ed. Frank Hentschel (Leiden: Brill, 1998), 269-9o, esp. 284-86. The Tractatus de duplici ritu cantus ecclesiastici in divinis officiis (ca. 1470?) of Gilles Carlier (ca. 1400-1472), French theologian and Dean of Cambrai Cathedral, appears to have served as an important model for Tinctoris's Complexus; see On the Dignity $\mathcal{E}$ the Effects, 6-22, and Barbara H. Haggh, "Carlerius, Egidius," in NG II.

109 (1) Brussels, Bibl. Royale Albert I ${ }^{\mathrm{er}}$, MS II 4147 , fols. $125^{\mathrm{r}-126 \mathrm{v}}$ (incomplete; on the possibility that this is an authorial holograph see Woodley, "Tinctoris's Italian Translation," 193-98); (2) Ghent, Universiteitsbibl., MS 7o, fols. $74 \mathrm{r}-77 \mathrm{v}$ (copied in Ghent in $15^{\circ} 3$ by Anthonius de Aggere Sancti Martini [probably Saint Martin at Akkerghem; see Woodley Proportionale 1: 141]); for descriptions of the ms. see Albert Derolez, The Library of Raphael de Marcatellis, abbot of St. Bavon's, Ghent, I437-1508 (Ghent: Story-Scientia, 1979), 227-34; RISM B-III ${ }^{1}, 65-69$. (3) Cambrai, Bibl. Mun., MS A416, fols. 1or-11v (copied probably late fifteenth century in north-east France; Woodley, "The Printing and Scope," $25^{8}$ ); see also n 106 above. 
copied in Obrecht's native city of Ghent in $15^{\circ}$, that we find the only reference to the composer in any of the theorist's 12 treatises. In this manuscript the description of the 19th effect, "Music glorifies those skilled in it" (Musica peritos in ea glorificat), includes a list of composers whom Tinctoris considers to be of the highest rank, those who have achieved "undying fame" for themselves. Such lists appear elsewhere in his treatises, but here three names are added to his usual roster-one Jacobus Carlerii, Robert Morton, and Obrecht.110 Different scholars have advanced reasons for believing these additions to be authorial rather than scribal in origin, reflecting revisions Tinctoris might have made to the treatise ca. $1480^{111}$ If true, this would mean that he already knew and valued Obrecht's music at a time when the composer was still probably in his early 20 and working as choirmaster of the Guild of Our Lady at Bergen op Zoom. ${ }^{112}$ While it is appealing to think that Obrecht's talents might have been recognized in distant Naples at such a young age, Strohm has detailed the weaknesses of this argument, pointing to the "local" nature of the Ghent manuscript's contents and its inferior status as a source for Tinctoris's text. ${ }^{113}$ Recent findings on the probable identity of the otherwise unknown Jacobus Carlerii further reinforce the local bias of the manuscript and make Tinctoris's

110 "In our own day, though, we have observed what great glory numerous musicians have achieved. For who does not know John Dunstaple, Guillaume Dufay, Gilles Binchois, Johannes Okeghem, Antoine Busnois, Johannes Regis, Firmin Caron, Jacobus Carlerii, Robert Morton, Jacob Obrechts [sic]? Who fails to bestow the highest accolades on those whose compositions, circulated throughout the civilised world, fill God's churches, kings' palaces and private houses with supreme sweetness?"; On the Dignity $\mathcal{E}$ the Effects, 60 .

${ }_{111}$ Woodley, "Tinctoris's Italian Translation," 192-94; Wegman, Born for the Muses, 73 .

112 On Obrecht's connections with Bergen op Zoom see Wegman, "Music and Musicians," 198-212, with further references to earlier literature at 198n48; idem, Born for the Muses, 79-81.

113 Strohm, introduction to On the Dignity $\mathcal{E}$ the Effects, 16-19. Not only was this manuscript copied in Ghent, it was made for Raphael de Marcatellis (1437-1 508), abbot of St. Bavo's in the same city (see n 109 above). Strohm notes also the other musical treatises copied there by the same scribe: in addition to the treatise of Gilles Carlier and the Complexus, there are four more of Tinctoris's works from the $147 \mathrm{Os}$ (Tractatus de notis et pausis, Tractatus alterationum, Liber imperfectionum musicalium notarum, and Proportionale musices), and De arte musicali by the Flemish scholar Denis the Carthusian (1394-1471), "whose views of music overlap in certain ways with those of the other two authors" (On the Dignity $\mathcal{E}$ the Effects, 17). Emphasizing the "far poorer quality" of the Ghent recension of the Complexus, Strohm notes that in most cases where it differs from the possible authorial holograph (Brussels, Bibl. Royale, MS II 4147), "it seems to add nonsense or trivial variations only." All of this makes it difficult to have much confidence in the mention of Carlerii and Obrecht having stemmed from Tinctoris. The Complexus circulated in northern France and the Low Countries in more than one version, and this sort of addition could easily have been made somewhere along the lines of transmission. 
awareness of Obrecht (at least at such an early date) look increasingly unlikely. ${ }^{114}$

If at present there is no credible evidence for the theorist having known about Obrecht, the text of Mille quingentis opens up for consideration a related and equally interesting issue, namely Obrecht's knowledge of the Complexus. And as the reader will perhaps have guessed, it is the treatise's many citations of earlier texts that are most relevant here. Strohm has drawn attention to the humanistic qualities of the Complexus, calling it Tinctoris's "most classicizing work," largely it seems on the basis of its many citations from antique writers. ${ }^{115}$ While the emphasis on classical sources is undeniable-especially striking are the 18 citations from Latin poetry-Strohm's description is potentially misleading in that it neglects the medieval precedents for this type of text. Christopher Page is much closer to the mark in saying that the treatise is "essentially a classified set of extracts from authorities plus a commentary." ${ }_{16}$ Though he does not use the term, what Page provides here is a concise definition of a florilegium, the textual genre to which the Complexus most clearly belongs.

Varying greatly in length and structure, these compilations of extracts-taken mostly from classical, biblical and patristic texts, with or without commentary-were very common between the 12 th and 16 th centuries and served a range of purposes. ${ }^{117}$ Surviving florilegia

114 No music survives under the name Jacobus Carlerii (or Carlier), in itself surprising given that he is here grouped with some of the most famous composers of the fifteenth century. David Fallows, ("Carlerii, Jacobus," in New Grove Dictionary of Music and Musicians, ed. Stanley Sadie [London: Macmillan, 1980]) has suggested that scribal error may have resulted in a wrong first name and that "Carlerii" is possibly Gilles Carlier, the French theologian whose musical treatise immediately precedes Tinctoris's Complexus in the Ghent manuscript (see n108 above). There is no evidence, however, that the eminent theologian was a composer. More recently, Daniel Lievois ("Carlerii, Jacobus," in NG II) has identified a priest named Jacob Carlier (d. 1457/58), who in the $145^{\text {os served as }}$ singer, vicar, and chaplain at the church of Our Lady in Bruges. Though more plausible certainly than the theologian, there is again no indication that this Carlier composed music. Given the Ghent origins of the manuscript, however, it is perhaps significant that this Jacob Carlier (according to Lievois) is likely the Jaquemyn Carlier named in the city accounts of Ghent in $145^{2-53}$ as a singer from the church of Our Lady.

115 Strohm, The Rise, 594 .

116 Page, "Reading and Reminiscence," 14.

117 The tradition of making such compilations extended much further back in time, even to antiquity; Carruthers The Book of Memory, $174-85$. On florilegia from the 12 th$15^{\text {th }}$ centuries that draw on classical and patristic authors see the essays by Birger Munk Olsen, Mary A. Rouse and Richard H. Rouse, and Jacqueline Hamesse in Les genres littéraires dans les sources théologiques et philosophiques médiévales: Définition, critique et exploitation. Actes du Colloque international de Louvain-la-Neuve 25-2 7 mai I 98 I (Louvain-la-Neuve: L'Institut d'Études Médiévales de L'Université Catholique de Louvain, 1982). As an example of the potential value of florilegia for music historians see Bruce W. Holsinger, "The Vision of Music in a Lollard Florilegium: Cantus in the Middle English Rosarium theologie (Cambridge, Gonville and Caius College MS 354/581)," Plainsong and Medieval Music 
include informal collections apparently intended for private use, as well as others designed for wider circulation, where often the compiler has provided a prologue explaining the ordering of the materials, their subject matter, and sometimes the broader ethical or religious value of the collection.118 The systematic arrangement of many florilegia according to ethical topics, vices and virtues, and the like, suggests they were read as moral handbooks of sorts, though it is increasingly clear that their importance as mnemonic and compositional tools for authors was considerable. For various medieval authors it can be shown that their seemingly encyclopedic knowledge of patristic and classical texts was in many instances the result of their having had recourse to florilegia. ${ }^{1} 9$

To see the collections simply as handy sourcebooks of readymade quotations, however, does justice neither to their users nor their compilers. The function of the florilegium as aide-mémoire was more comprehensive than this, linked as it was to mnemonic practices of varying degrees of formality. Such a compilation could be "a promptbook for memoria" - the systematic and well-stocked storehouse of what one had read and studied-with the extracts serving in part as mnemonic tags, 450 allowing the compiler or later reader to recall more extended sections of the work from which a given passage was taken. ${ }^{120}$ In this way the florilegium was the embodiment of an approach to reading and understanding that was characterized by a fragmentation of texts. ${ }^{121}$ The roots of this fragmentation lay in pedagogical traditions: the student copying and memorizing individual verses or brief passages, the teacher

8 (1999): 95-106. Citing Page's description of the Complexus, Holsinger refers to Tinctoris's "florilegial mentality" and raises it as a possibility that "the Complexus may well have been derived precisely from another such 'classified set' available to him in manuscript or print." In fact, it has already been established that Tinctoris relied for a number of his biblical and medieval citations on an earlier treatise on music by Gilles Carlier; see On the Dignity $\mathcal{E}$ the Effects, 10-1 2 and n103 above.

${ }_{118}$ Jacqueline Hamesse, "Les florilèges philosophiques du XIII ${ }^{\mathrm{e}}$ au XV $\mathrm{XV}^{\mathrm{e}}$ siècle," in Les genres litteraires, 181-91. Carruthers notes the preface to the 14th-century English Florarium Bartholomei, where the compiler (an Augustinian canon) says that the collection provides materials "which every Christian soul needs for its virtuous behaviour and its salvation." He goes on to specify how one should read the florilegium: "Understand, however, that [these texts] are not to be read amidst tumults, but in quiet; not speedily, but one subject at a time, with intent and thoughtful meditation" (quoted in Carruthers, The Book of Memory, 184).

119 The value of florilegia as sourcebooks for writers is doubtless one of the reasons why such compilations often survive in many copies, in some cases numbering in the hundreds; see Mary A. Rouse, "Florilegia," in Dictionary of the Middle Ages, ed. Joseph R. Strayer (New York: Charles Scribner's Sons, 1982).

120 Carruthers, The Book of Memory, 176.

121 On the effects of this fragmentation on how longer texts such as the Aeneid were studied and utilized see Kallendorf, Virgil and the Myth of Venice, 67-77. 
isolating a phrase or word for purposes of grammatical or allegorical explication. It followed from such training that the reader/writer would extract and collect particular lines, sententiae, ethical or devotional maxims from a variety of sources as a tool for composing his or her own texts. ${ }^{122}$ Page is certainly right to point to Tinctoris's legal studies as a context in which mnemonic practices of this sort would have been especially pronounced, but owing to the high value placed on a wellstocked memory, one that was both copious and organized, its cultivation figured strongly in education at all levels throughout the medieval period and beyond. ${ }^{123}$

Obrecht's own university training, wherever it occurred, would have entailed a comparable development of his memoria, and presented with the Complexus he would surely have recognized it as belonging to a class of texts with which he was familiar, even if the specific topic was an unusual one for such compilations of extracts. But did he ever actually read Tinctoris's florilegium on the effects of music? Based on the evidence of another of Obrecht's motets preserved in the Segovia Choirbook, it seems almost certain that he had read at least one of the theorist's other treatises quite carefully. Helen Hewitt first discussed Obrecht's two-voice Regina caeli, with its series of cumulative proportional relationships handled in a manner that accords with Tinctoris's principles as laid out in his Proportionale musices (ca. 1472/73). ${ }^{124}$ As Wegman notes, "the strongly Tinctorian bent in the piece suggests not only thorough acquaintance with the Proportionale, but unqualified acceptance of its most innovatory teachings." ${ }^{25}$ The Complexus dates also from the early to mid $147 \mathrm{Os}$, and more than one version of it was circulating in the North perhaps already in the early-to-mid 1480s. Given Obrecht's interest in the teachings of Tinctoris, he might well have sought out the work. Turning back to Mille quingentis and to texts that could have mediated Obrecht's use of Vergil's poetry, a closer look at the contents of the Complexus reveals it to be a promising candidate.

There is first of all Tinctoris's reliance on Vergil. With 11 citations, he is the most quoted author in the Complexus; only the Bible is cited

122 As Christopher Baswell points out, it is the medieval, grammar-based pedagogical tradition that provided clerics with the materials necessary for their more complex allegorical interpretations of the Aeneid and other classical works; see his Virgil in Medieval England, 9-13, and 101-07.

123 Page, "Reading and Reminiscence," $13^{-1} 4$.

124 Helen Hewitt, "A Study in Proportions," in Essays on Music in Honor of Archibald Thompson Davison (Cambridge: Dept. of Music, Harvard Univ., 1957), 69-81.

125 Wegman, Born for the Muses, 75, where it is further suggested that this motet "is a reflection of Obrecht's university education, perhaps of his teaching as a bachelor or master of arts." Bonnie Blackburn notes that Regina caeli represents an exception to Obrecht's otherwise consistent practice of using mensuration signs to indicate proportions (private communication). 
more often (13 times). ${ }^{126}$ Despite Vergil's cultural status, this emphasis on his poetry is unusual for a florilegium. Going back to the 12 th century, when some of the most widely disseminated florilegia were created, there was a clear preference among compilers of extracts for certain of the Latin poets. Ovid, Horace, Juvenal, Martial, all are much more heavily represented than Vergil, possibly because their poetry lent itself more readily to very brief quotation. ${ }^{127}$ Some of the Vergil excerpts that do appear in a number of florilegia are long (ranging from 10 lines to over 200). As it was in the nature of such collections that a compiler would take over many of the selections he encountered in earlier sources (not unlike modern anthologists), this preference for more succinctly "quotable" authors persisted. The moral overtones of Tinctoris's compilation, though something shared by many florilegia from all periods, might account for his leaning toward Vergil's poetry, which in the $15^{\text {th }}$ century was increasingly read as moral philosophy (especially

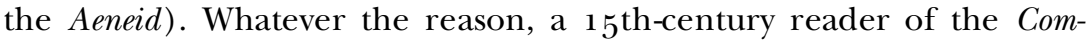
plexus could hardly have missed the strong presence there of Vergil: citations not only from the Aeneid (six times), but also the Georgics (three times) and the Eclogues (twice) are spread throughout the work and are used to illustrate nine of music's 20 effects. ${ }^{128}$

Here I will focus on just two of the Vergil quotations, both of which appear under the seventh effect, "Music drives away sadness" (Musica tristitiam depellit). This is the only place in the treatise where Tinctoris addresses the idea of music as solace, its power to console in times of grief. He provides three citations, the first of which is biblical, from the Epistle of James 5.13: "Is any of you sad? Let him pray. Is any in good heart? Let him sing psalms." ${ }_{29}$ Here we have a good example of a brief quotation functioning as a mnemonic tag. At first glance this hardly seems an apt illustration of music's power to drive away sadness. On the contrary, we are told to sing (psallat) when "in good heart." In trying to account for Tinctoris's choice one could note that this excerpt is one of

${ }^{126}$ In the only extant letter of Tinctoris, addressed to the Neapolitan court scribe Joanmarco Cinico, he quotes a passage from Aen. 6, referring to its author as ille maximus atque optimus poeta Virgilius; see Woodley, "Tinctoris's Italian Translation," 238. Woodley proposes a date of ca. $1495 / 96$ for the letter. I am grateful to Bonnie Blackburn for bringing this passage to my attention. Other classical authors cited in the Complexus include Quintilian (eight references to his Institutio oratoria), Aristotle (five references, all to Politics Bk. 8), Cicero (twice), and various Latin poets (Ovid, Horace, Juvenal, and Statius).

127 Berthold L. Ullman, "Vergil in Certain Medieval Florilegia," Studi medievali 5 (1932): 59-66.

${ }_{128}$ On the Dignity $\mathcal{E}^{2}$ the Effects, $5^{1-80}$.

129 Tristatur aliquis vestrum? oret. Aequo animo est? psallat; On the Dignity $\mathcal{G}$ the Effects, 55,70 . 
several from the Bible that Tinctoris took over-directly it seems-from Gilles Carlier's slightly earlier treatise (ca. 1470?) on the use of music in divine services. ${ }^{30}$ However in Carlier's work, too, this excerpt from James appears ill-suited to the context in which it is mentioned.131 Recognition of the appropriateness of the citation depends on a knowledge of the passages in James that surround these lines, where the subject is precisely that of suffering and how the faithful should respond to it. In other words, what both Tinctoris and Carlier presuppose in the reader is a memoria that includes this longer passage, either the actual text (ad verba) or its general outline (ad res). The excerpt is thus a mnemonic pointer, the sort of prompt for memoria that Mary Carruthers has shown to have been so characteristic of florilegia. ${ }^{132}$

Tinctoris immediately follows this biblical illustration of music's power to dispel sadness with two passages taken from the works of Vergil. As in many florilegia, Tinctoris signals the sources of his citations with some precision (in this case Aeneid Bk. 3 and Georgics Bk. 4), further indication of a mindset that viewed such extracts at least in part as mnemonic tags. Most striking in terms of the present discussion is that both these excerpts from Vergil point the reader to passages in his poetry related to the Vergilian elements in Mille quingentis. Tinctoris

gives the first of the two citations without comment, except to specify the source and the character to whom the line applies:

This is why in the third book of the Aeneid Vergil says of Polyphemus: 'As comfort in misfortune, a pipe hangs from his neck.' 133

Here again the relevance of the quotation to Tinctoris's seventh effect depends to an extent on the reader's recollection of its original context. Polyphemus is one of the cyclopes described as inhabiting the area around Mt. Etna, and his misfortune was to have been blinded by the followers of Ulysses. The reference in the Complexus is to Aen. 3.666 and makes up part of Vergil's description of Polyphemus at the moment he is first sighted by the Aeneadae. Quite apart from the association of the

130 On the Dignity $\mathcal{E}$ the Effects, 11 ; on Carlier's treatise see $\mathrm{n} 108$ above.

${ }_{131}$ The citation appears in a section of Carlier's treatise devoted to "the second special claim of music," namely that it "tempers mental passions." The other quotations he provides there are mostly drawn from famous classical accounts of music calming the anger or inflamed passions of youths; On the Dignity $\mathcal{E}^{2}$ the Effects, 27-28.

${ }_{132}$ Carruthers, The Book of Memory, 174-77.

133 Hinc de Poliphemo Vergilius in tertio libro Aeneidos ait: "Solamenque mali de collo fistula pendet." Trans. after On the Dignity $\mathcal{E}^{2}$ the Effects, 55 (Latin text, 71). All $15^{\text {th-century copies }}$ of the Aeneid give this line as Tinctoris has it, though only the first two words actually go back to Vergil. This is one of the numerous incomplete lines found in the epic which later writers filled out. 
cyclopes and Sicily, we will recall that it is precisely the sudden appearance of Polyphemus that causes the Trojans to flee, setting in motion their journey along the Sicilian coastline, which ends with Anchises's death at Drepanum and Aeneas's subsequent lament.

The second Vergil citation is more obviously "musical" in that it concerns Orpheus. Not surprisingly there are several references in the Complexus to this most potent symbol of the effects music can produce, with the quotations drawn from Vergil, Ovid, and Quintilian. The mention of him here, however, is the only one in the work that employs the image of the miserabilis Orpheus, he who laments the death of Eurydice and who figures so prominently in the fourth book of Vergil's Georgics. Accordingly the theorist prefaces the citation with a brief explanatory note:

And since most sadness occurs in love, it is music that often banishes this with its natural power to comfort. Hence Vergil, again, in the fourth book of the Georgics describes Orpheus, saddened by the loss of Euridice, whom he passionately loved, finding comfort in his special instrument: "he went solacing his bitter love with the hollow lyre, singing of you, sweet wife, alone on the shore by himself, singing of you, as the day arose, you, as the day declined. ${ }^{1}{ }^{134}$

The connection with Mille quingentis in this case involves not the allusion in lines $5^{-6}$ of the motet text to Anchises traveling the Sicilian shore, but rather the Vergil-cento that makes up line 3. As mentioned previously, the passage in Vergil from which Tinctoris has extracted this citation seems to have been the source for one of the significant words in Obrecht's line 3, flerunt. Just three lines prior to the point where Tinctoris begins his citation we find the only occurrence of flerunt in Vergil's poetry. ${ }^{135}$

${ }_{134}$ Trans. after On the Dignity $\mathcal{E}$ the Effects, 55 (for Vergil's text I have adapted the translation in Parry, "The Idea of Art," 48 ; see $n_{5} 8$ above).

135 In this same Vergilian context, the motet's reference to "the Orphic Jacob" perhaps takes on wider meaning. Obrecht, having drawn the parallel between, on the one hand, himself and Willem, and on the other, Aeneas and Anchises, goes on to exploit the dual characterisation of Orpheus. Not only is Orpheus the archetypal musician of skill and charm, he also laments the dead and travels to the underworld. In Aeneid 6.103-123, Aeneas appeals to the Sibyl of Cumae to help him visit his deceased father in the underworld. To strengthen his case Aeneas cites various precedents: "Pity a son and a father, gracious lady ... If Orpheus could call his wife's shade up, relying on the strings that sang loud on his Thracian lyre; if Pollux redeemed his brother, taking his turn at death, so often passing back and forth; why name the heroes, Theseus and Hercules? By birth I too descend from Jove on high" (trans. Fitzgerald, 163-64). Aeneas, in emulation of Orpheus, wishes to see his father. Obrecht, in emulation of Aeneas, becomes the "Orphic Jacob" who through his music calls up and comforts the spirit of Willem. It is interesting to note that one of the Sibyl's conditions for leading Aeneas to the underworld is that he 
Could it be that it was Obrecht's reading of the Complexus that prompted him to turn to Vergil in the first place? In composing a poem such as Mille quingentis there would have been nothing unusual in Obrecht consulting a florilegium in search of appropriate topoi. As a musical son commemorating a musical father it would have been only natural for him to seek out a florilegium on music, perhaps especially one prepared by Tinctoris, with whose authority in musical matters he was already familiar. Moreover, the text of Mille quingentis refers explicitly to the spiritual effects of music: "therefore sweetly sing this song, gentle choir of succentors, so that his soul may be carried to Heaven and be given the palm." Obrecht did not need Tinctoris to arrive at such a conception of music's spiritual agency; his own cultural upbringing would have taken care of that. But that upbringing was something Tinctoris had experienced as well, and the congruence of their views on this aspect of music makes it all the more likely that the Complexus was a work in which Obrecht would have been interested.

One focus of this study has been the hybrid nature of Obrecht's text. Having examined a wide range of possible background sources, we see that this description applies equally to the finished result-the poem-and to the manner in which its author drew on the various textual and literary traditions that seem to lie behind it: the formulaic medieval verse epitaph, the poetry of Vergil as seen through the prisms of its medieval and humanistic refashionings, the Christian assimilation of classical themes and motifs, the florilegium. There may be reasons for preferring certain of these over others as more proximate influences on the writing of Mille quingentis. Given Obrecht's career and the period in which he lived, however, it is possible-likely even-that he would have been exposed to all these different practices and traditions to some extent, in which case it is precisely the poem's overlapping of textual types that would seem the more important point to pursue as we attempt to understand the scope of his intellectual background and interests.

Finally, the motet's text raises issues of social identity and status

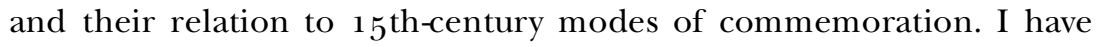

bury his friend, of whose death he is as yet unaware. Subdued, Aeneas, accompanied by Achates, walks to the shore, where they find the body of Misenus, "a son of Aelous, never surpassed at rousing fighting men with brazen trumpet, setting Mars afire" (Fitzgerald, $165)$. The unexpected death of this trumpeter without equal is mentioned just forty lines after the reference to Orpheus. That the passage may have struck a responsive chord in the son of a recently deceased trumpeter must remain a speculation, though the proximity of the passages, as well as the larger context in which they occur, are suggestive. See also Laura Bocciolini Palagi, "Enea come Orfeo," Maia $4^{2}$ (199o): 133-150, where the figure of Aeneas is linked with the miserabilis Orpheus of the Georgics. 
suggested the poem's commemorative significance would have stemmed in part from how one read and remembered various well-known texts from antiquity. Through a process of assimilation and identification, Willem Obrecht could become an Anchises-figure, with Jacob himself linked with pius Aeneas, the ideal of the devoted son, who carried his father from the ashes of Troy, lamented his father's death in Sicily, and then returned on the anniversary to carry out the ritual of the funeral

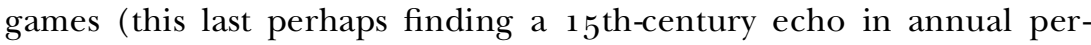
formances of Mille quingentis on the anniversary of Willem's death). All of this seems to me germane to the poem's textual surface and its diverse resonances. But this is also a text that concerns the lives of musicians, and a complement to the ideas presented here would be an examination of the social forces that could color one musician's commemoration of another. A modest verse epitaph adorned with markers of an elite Latin culture: Where within the broad spectrum of $15^{\text {th- }}$ century devotional texts should we situate such a poem? The question is a complex one, with ramifications far beyond this single work. Obrecht's motet, understood as a form of cultural aspiration, reflects a conflict inherent in the social existence of many musicians of the time.

456 While education and employment could embed musicians in the dominant cultures of civic, ecclesiastical, and courtly institutions, their status within these institutions was often marginal. Poetic language could not undo this social reality, and perhaps Jacob's best hope was to bestow on Willem a degree of honor he could hardly have enjoyed in life. With these thoughts in mind, the web of allusions in Mille quingentis prompts us to consider more fully the impact of a social environment in which Obrecht should have chosen to commemorate the life of a city trumpeter by making him into the father of a hero.

The University of North Carolina at Chapel Hill

\section{ABSTRACT}

Efforts to uncover biographical data in the text of Jacob Obrecht's motet Mille quingentis have led scholars to minimize the significance of the poem's figurative language. Written in response to the death of the composer's father, the text is a hybrid of different poetic styles, a reflection of the rich web of literary and cultural practices that lies behind it. Allusions to the poetry of Vergil figure more prominently in the motet than has been previously recognized. Other examples of the kinds of allusions found in Mille quingentis, drawn from a wide range of works, demonstrate that Obrecht was here participating in a more general 
commemorative practice, wherein the assimilation of well-known classical texts served to express private sentiments using a "public" language newly charged with meaning. A consideration of texts that possibly mediated his use of Vergilian language and themes (among them a treatise of Johannes Tinctoris) suggests that the motet's biographical significance lies principally in what it can tell us about Obrecht's intellectual background and tendencies, as well as his engagement with the humanistic literary environment he would have encountered during his first stay at the Ferrarese court. 